\title{
Hemolymph composition, gene expressions in the gills, and thus the survival of euryhaline crabs are controlled by ambient minor cations according to osmotic condition-dependent manner
}

\author{
Masahiro Yamaguchi ${ }^{1}$ and Kouichi Soga ${ }^{2}$ \\ ${ }^{1}$ National Institute of Technology, Suzuka College \\ ${ }^{2}$ Osaka City University Graduate School of Science Faculty of Science
}

August 17, 2020

\begin{abstract}
$\mathrm{Na}+$ and $\mathrm{Cl}-$ are the most abundant dissolved ions in seawater, constituting $\sim 85 \%$ of total ions. They significantly affect the osmolality of body fluids of marine invertebrates. Seawater also contains minor ions such as $\mathrm{Mg} 2+, \mathrm{Ca} 2+, \mathrm{K}+$, and $\mathrm{SO} 42-$, but their effects on marine organisms are unclear. This study analyzed the effects of $\mathrm{Mg} 2+, \mathrm{Ca} 2+$, and $\mathrm{K}+$ (ambient minor cations) on survival, hemolymph ionic composition, and gene expression in the gills of three euryhaline crabs: Helice tridens, Macrophthalmus japonicus, and Chiromantes dehaani. Ambient minor cations were required for survival of H. tridens and M. japonicus under isosmotic conditions with seawater. The ambient minor cations also affected the osmolality and ionic composition of hemolymph by regulating expressions of specific genes in the gills required for $\mathrm{Na}+$ uptake, such as $\mathrm{Na}+/ \mathrm{K}+\mathrm{ATPase}$, cytoplasmic carbonic anhydrase, and $\mathrm{Na}+/ \mathrm{H}+$ exchanger. Administration of carbonic anhydrase and $\mathrm{Na}+/ \mathrm{H}+$ exchanger inhibitors increased the survival rate even if ambient minor cations did not exist. In contrast, under hypo-osmotic conditions, ambient minor cations had different effects on crabs; a lethal effect on M. japonicus, and an increase of the hemolymph $\mathrm{K}+$ concentration in H. tridens and M. japonicus. It is thus concluded that the effects of ambient minor cations are osmolality-dependent. In contrast, in C. dehaani, the hemolymph ionic composition and survival rate were hardly affected by ambient minor cations, probably reflecting the habitat of this species. These results strongly indicated that C. dehaani is less susceptive to ambient minor cations compared to H. tridens and M. japonicus.
\end{abstract}

\section{1| INTRODUCTION}

Dissolved ions in seawater play a crucial role in maintaining the osmolality of body fluids of marine invertebrates. $\mathrm{Na}^{+}$and $\mathrm{Cl}^{-}$are the most abundant ions in seawater, constituting $\sim 85 \%$ of total ions, in addition to minor ions such as $\mathrm{SO}_{4}{ }^{2-}, \mathrm{Mg}^{2+}, \mathrm{Ca}^{2+}$, and $\mathrm{K}^{+}$. If dissolved ions are required only for maintaining the osmolality of body fluids, minor ions should not be essential and their replacement by $\mathrm{Na}^{+}$and $\mathrm{Cl}^{-}$should have no effect on the life of marine invertebrates. However, the euryhaline prawn Penaeus mondoncannot survive in $0.17 \% \mathrm{NaCl}$ solution, although it can survive in diluted artificial seawater of the same salinity (Cawthorne et al., 1983). In addition, the presence of $\mathrm{K}^{+}, \mathrm{Mg}^{2+}$, and $\mathrm{SO}_{4}{ }^{2-}$ increases the survival rate of euryhaline prawns Litopenaeus vannamei and Melicertus latisulcatus (formerly called P. latisulcatus) (Saoud et al., 2003; Zhu et al., 2004; Davis et al., 2005; Prangnell and Fotedar, 2005, 2006; Roy et al., 2007). Therefore, minor ions are required for the survival of marine invertebrates, at least for some euryhaline crustaceans. However, the mechanisms by which minor ions affect the survival of marine organisms are unclear.

Most crustacean species inhabiting estuaries are osmoregulators; they can regulate hemolymph osmotic and ionic concentrations in response to ambient salinity changes to some extent. Typical osmoregulation in estuarine crustaceans is hyper-isosmotic, with hyperregulation in low salinity and isosmotic regulation in salinity close to or higher than seawater (Charmantier et al., 2009; Lignot and Charmantier, 2015). Such 
osmoregulatory pattern allows crustacean species in estuaries to be euryhaline and tolerate a wider range of ambient salinity. Many studies have investigated the mechanisms by which euryhaline crabs exposed to fresh/brackish water maintain their hemolymph osmolality higher compared to the environment, and chloride cells in posterior gills play an important role in hemolymph osmotic and ionic regulation (Freire et al., 2008; Henry et al., 2012). Chloride cells express $\mathrm{Na}^{+} / \mathrm{K}^{+}$ATPase (NKA) in the basolateral membrane, which transports $\mathrm{Na}^{+}$from the cytoplasm to the hemolymph and maintains intracellular $\mathrm{Na}^{+}$concentration relatively low. Another key enzyme in chloride cells is cytoplasmic carbonic anhydrase (CAc), which catalyzes the formation of $\mathrm{H}^{+}$and $\mathrm{HCO}_{3}{ }^{-}$from $\mathrm{H}_{2} \mathrm{O}$ and $\mathrm{CO}_{2}$, and the derived $\mathrm{H}^{+}$supports $\mathrm{Na}^{+}$uptake through activation of the $\mathrm{Na}^{+} / \mathrm{H}^{+}$exchanger (NHE) located in the apical membrane. Other molecules, such as Vtype $\mathrm{H}^{+}$ATPase and $\mathrm{Na}^{+} / \mathrm{K}^{+} / 2 \mathrm{Cl}^{-}$cotransporter (NKCC), are also involved in regulating salinity and ionic composition of hemolymph (Freire et al., 2008; Charmantier et al., 2009; Henry et al., 2012; Griffith, 2017). Transcriptome analysis has identified numerous genes whose expression levels are modified by changes in ambient salinity (Towle et al., 2011; Lv et al., 2013), and these genes might also contribute to hemolymph osmotic and ionic regulation. However, it is unknown at present what factor(s) in environmental water are used as key signal of ambient salinity, and what factor(s) induce changes of the gene expressions in the gills.

This study analyzed the effects of $\mathrm{Mg}^{2+}, \mathrm{Ca}^{2+}$, and $\mathrm{K}^{+}$(hereafter called "ambient minor cations") on survival, hemolymph ionic composition, and gene expression in the gills of three euryhaline crabs: Helice tridens , Macrophthalmus japonicus, and Chiromantes dehaani. The different response to ambient minor cations between euryhaline species could be due to the difference in the microenvironment of their habitats or phylogeny.

\section{2| MATERIALS AND METHODS}

\section{1| Animals and evaluation of survival rates in various bathing media}

H. tridens and M. japonicus were collected from the Tanaka river estuary in Tsu City. C. dehaani was collected from the Suzuka river estuary in Yokkaichi City, Mie Prefecture, Japan. In order to examine the effects of ionic composition of bathing media on survival rate, four individuals of each species were reared in $210 \times 300 \times 95 \mathrm{~mm}$ plastic tanks with $1000 \mathrm{~mL}$ of bathing media (for H. tridens and C. dehaani), or in $177 \times 195 \times 100 \mathrm{~mm}$ plastic tanks with $500 \mathrm{~mL}$ of bathing media (for $M$. japonicus ). The compositions of bathing media used in this study were summarized in Table 1 . The tanks were kept in an incubator in a 16 $\mathrm{h} / 8 \mathrm{~h} \mathrm{light} /$ dark cycle at $21^{\circ} \mathrm{C}$. The survival rate of crabs was assessed at $16,24,40$, and $48 \mathrm{~h}$, and carcasses were removed at each time point. The survival rate at $48 \mathrm{~h}$ was calculated and presented unless otherwise noted. The experiments were performed at least in triplicate.

\section{2| Carbonic anhydrase and $\mathrm{Na}^{+} / \mathrm{H}^{+}$exchanger inhibitors}

Acetazolamide and amiloride hydrochloride hydrate, which have already been used in crustacean studies (Burnett and Towle, 1990; Henry et al., 2003; Genovese et al., 2005; Tresguerres et al., 2008), were used as inhibitors for carbonic anhydrase (CA) and the NHE, respectively. Acetazolamide was dissolved in dimethyl sulfoxide (DMSO) to prepare a $200 \mathrm{mg} / \mathrm{mL}(1.11 \mathrm{~mol} / \mathrm{L})$ stock solution. In order to assess the effect of acetazolamide on survivals, four individuals of the crabs were reared in natural seawater containing $1 \mathrm{mg} / \mathrm{mL}$ $(5.6 \mathrm{mmol} / \mathrm{L})$ of acetazolamide 2 days prior to experiments and then transferred to the $3 \% \mathrm{NaCl}$ solution containing $1 \mathrm{mg} / \mathrm{mL}$ of acetazolamide. As the control group, the same number of the crabs were also reared in natural seawater and then transferred to the $3 \% \mathrm{NaCl}$ solution supplemented only with DMSO. Amiloride hydrochloride hydrate was dissolved in DMSO to prepare a $50 \mathrm{mg} / \mathrm{mL}(187.9 \mathrm{mmol} / \mathrm{L})$ stock solution. In order to assess the effect of amiloride on survivals, four individuals of the crabs were reared in $513.3 \mathrm{mmol} / \mathrm{L}$ $\mathrm{NaCl}$ solution containing $0.25 \mathrm{mg} / \mathrm{mL}(0.9 \mathrm{mmol} / \mathrm{L})$ of amiloride hydrochloride hydrate. The control group was reared in $513.3 \mathrm{mmol} / \mathrm{L} \mathrm{NaCl}$ containing only DMSO. The survival rate was calculated $24 \mathrm{~h}$ after transfer. The experiments were performed at least in triplicate.

\section{3| Hemolymph $\mathrm{Na}^{+}$,}

$\mathrm{K}^{+}$, and osmotic concentrations 
The crabs were anesthetized and dissected, and $\sim 300 \mu \mathrm{l}$ (for H. tridens and C. dehaani) or $\sim 150 \mu \mathrm{l}$ (for M. japonicus ) of hemolymph was collected from each crab. They were centrifuged at $2390 \times \mathrm{g}$ for $5 \mathrm{~min}$ at $4^{\circ} \mathrm{C}$ and the supernatant was collected to be used as the sample solution. $\mathrm{Na}^{+}$and $\mathrm{K}^{+}$concentrations in 1:10 diluted and undiluted sample solutions, respectively, were measured using sodium (model C-122) and potassium ion meters (model C-131) (HORIBA, Kyoto, Japan), respectively. The osmotic concentrations were measured with a vapor pressure osmometer (Model 5600, Wescor, Logan, UT, USA).

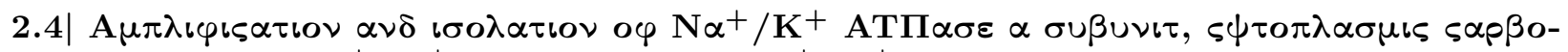

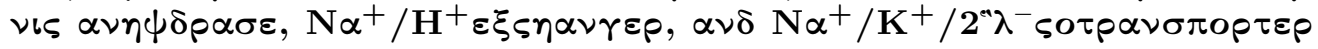

Amplification and isolation of complementary DNAs (cDNAs) encoding NKA $\alpha$ subunit, CAc, NHE, and NKCC in H. tridens, $M$. japonicus, and $C$. dehaani were performed, as previously described (Yamaguchi and Wakahara, 2001). Briefly, the most posterior pair of gills was isolated from crabs, and total RNA was extracted using Isogen reagent (Nippon Gene, Tokyo, Japan) according to the manufacturer's instructions. cDNAs were synthesized using an oligo (dT) primer and ReverTra Ace (TOYOBO, Osaka, Japan), and resultant cDNAs served as templates for polymerase chain reaction (PCR) amplification. Degenerate primers were designed on the basis of the amino acid sequence of the gene products in Callinectes sapidus, Carcinus maenas ,Portunus trituberculatus, and L. vannamei. The primer sequences used for PCR were as follows: NKA $\alpha$ subunit: forward, 5'-ATGACNGTNGCNCAYATGTGG-3'; reverse, 5'-GGRTGRTCNCCNGTNACCAT3'; CAc: forward, 5'-TAYGTNTTRGARCARTTYCA-3' or 5' -TAYGTNCTNGARCARTTYCA3'; reverse, 5'-CKRAANGCRTCYAAYTG-3' or 5'-CKRAANGCRTCNAGYTG-3'; NHE: forward, 5'AARATHGGNTTYCAYATGAC-3'; reverse, 5'-TGYTCNACRTARTTYTTCAT-3'; NKCC: forward, 5'AAYATHTGGGGNGTNATG-3'; reverse, 5'-GCRAARCANCCNGCRTADAT-3'.

For amplification of CAc and NKCC cDNA, we performed nested PCR using part of the products from the first amplification as a template. The primer sequences used for nested PCR were as follows: CAc: forward, 5'-CAYTGGGGNAARACNAAYGA-3'; reverse, 5'-CANGGNGGNGTNGTNA-3'; NKCC: forward, 5'ATHTGGGGNGTNATGYT-3'; reverse, 5'-ARYTCCATNACYTGRAARCT-3'.

In every case, conditions for PCR were as follows: 40 cycles for $30 \mathrm{~s}$ at $94^{\circ} \mathrm{C}, 30 \mathrm{~s}$ at annealing temperature, and $30 \mathrm{~s}$ at $72^{\circ} \mathrm{C}$. The annealing temperature for NKA $\alpha$ subunit, CAc, NHE, and NKCC was $50^{\circ} \mathrm{C}$, $43^{\circ} \mathrm{C}, 45^{\circ} \mathrm{C}$, and $45^{\circ} \mathrm{C}$, respectively. Amplified PCR products were electrophoresed and extracted, and then inserted into a pTA2 cloning vector (TOYOBO), and finally, their nucleotide sequences were determined. The sequences of isolated cDNAs were deposited to GenBank (Accession numbers of NKA $\alpha$ subunit, CAc, NHE, and NKCC are LC214855, LC375964, LC572286, and LC572287 for H. tridens, LC214856, LC375965, LC572288, and LC572289 for M, japonicus, and LC572290, LC572291, LC572292, and LC572293 for C. dehaani ). In addition, amino acid sequences were predicted from the cDNA fragment sequences of $H$. tridens, M. japonicus, and C. dehaani and compared with those of the shore crab C. maenas (GenBank Accession numbers are AY03550, EU273943, U09274, and AY035548 for NKA a subunit, CAc, NHE, and NKCC, respectively) (Towle et al., 1997; Serrano and Henry, 2008).

\section{5| Northern blotting}

Northern blotting was performed, as previously described (Yamaguchi et al., 2000). Briefly, using cDNA fragments for genes encoding NKA $\alpha$ subunit, CAc, NHE, and NKCC as templates, digoxigenin-labeled RNA probes were synthesized according to the manufacturer's instructions for the 10x DIG RNA labeling mix (Roche, Basel, Switzerland). Total RNA was extracted from the most posterior pair of gills using Isogen reagent (Nippon Gene), and $8.5 \mu \mathrm{g}$ of total RNA was electrophoresed in $1 \%$ agarose gel containing $1 \mathrm{x} 3-(N$ -morpholino)propanesulfonic acid (MOPS) and $5.5 \%$ formalin. Next, RNA was transferred from the gel to a positively charged nylon membrane (Roche) overnight. The resultant membrane was prehybridized using a solution containing $5 \mathrm{x}$ saline-sodium citrate (SSC), $50 \%$ formamide, $5 \mathrm{x}$ Denhardt's solution, $0.5 \%$ sodium dodecyl sulfate (SDS), and $0.005 \%$ transfer RNA (tRNA) and then hybridized with digoxigenin-labeled RNA probes overnight. Finally, the membrane was washed, blocked, and treated with alkaline phosphataseconjugated anti-digoxigenin antibody (Roche) at a dilution of 1:2000. Signals were detected using nitro blue 
tetrazolium and 5-bromo-4-chloro-3-indolyl-phosphate. The intensity of detected signals of Northern blotting was normalized with amount of electrophoresed ribosomal RNA, both of which were quantified using image processing program, ImageJ (National Institute of Health, Maryland, USA). The relative expression level was calculated as the expression in $513.3 \mathrm{mmol} / \mathrm{L} \mathrm{NaCl}+\mathrm{MCK}$ (Fig. 5 ) or $4.3 \mathrm{mmol} / \mathrm{N} \mathrm{NaCl}$ solution (Fig. 9) was 1.0.

\section{6| RNase protection assay}

RNase protection assay was performed according to Sugiyama et al. (Sugiyama et al., 2001). Briefly, total RNA was extracted from the most posterior pair of gills and hybridized with digoxigenin-labeled RNA probes overnight. Next, RNA was treated with RNase A and RNase T1 to digest single-stranded RNA and electrophoresed in $1 \%$ agarose gel containing $1 \mathrm{x}$ MOPS and $5.5 \%$ formalin. Subsequently, RNA was transferred from the gel to a positively charged nylon membrane (Roche) overnight. Finally, the membrane was blocked and then treated with alkaline phosphatase-conjugated anti-digoxigenin antibody (Roche) at a dilution of 1:2000. Signals were detected using nitro blue tetrazolium and 5-bromo-4-chloro-3-indolylphosphate. The intensity of the signals was quantified and the relative expression levels were determined as in Northern blotting.

\section{7| Statistical analysis}

All rearing experiments to evaluate survival rates were performed at least in triplicate, and $\mathrm{Na}^{+}, \mathrm{K}^{+}$, and osmotic concentrations were measured in at least three crabs in each group. Error bars in the figures show standard errors. Mean values comparisons among more than three groups were performed using analysis of variance (ANOVA), followed by Williams' test, Student's $t$-test with Bonferroni correction, or Tukey's test. Mean values comparisons between two groups were performed by Student's $t$-test. Results were considered statistically significant if the $P$ value was less than 0.05 .

\section{3| RESULTS}

\section{1| Effects of ambient minor cations on survival and hemolymph composition of euryhaline crabs under isosmotic conditions}

To investigate effect of minor cations on survivals of euryhaline crabs, $H$. tridens, $M$. japonicus, and $C$. dehaani were reared in 8.0, 16.0, 32.1, 64.2, 128.3, 256.7, and $513.3 \mathrm{mmol} / \mathrm{L} \mathrm{NaCl}$ solution (i.e., $513.3 \mathrm{mmol} / \mathrm{L}$ $\mathrm{NaCl}$ solution was geometrically diluted with a factor of 2.0) and natural seawater. The survival rate of all of three species was $100 \%$ in natural seawater and relatively high in $8.0 \mathrm{mmol} / \mathrm{L} \mathrm{NaCl}$ solution (Fig. 1), indicating that all three species are strongly euryhaline and are hyperregulators in low salinity. However, the survival rate significantly decreased in $H$. tridens and $M$. japonicus at higher $\mathrm{NaCl}$ concentrations, and the majority of crabs (most of $H$. tridens and all of $M$. japonicus) died in $513.3 \mathrm{mmol} / \mathrm{L} \mathrm{NaCl}$ solution, although its salinity was comparable to that of seawater (Fig. 1A, B). The few H. tridens individuals who survived in $513.3 \mathrm{mmol} / \mathrm{L} \mathrm{NaCl}$ solution were moribund. These results showed that $513.3 \mathrm{mmol} / \mathrm{L} \mathrm{NaCl}$ solution without minor cations caused severe damage in crabs. Profit analysis revealed that median lethal concentrations $\left(\mathrm{LC}_{50}\right)$ for $H$. tridens and $M$. japonicus were $431.57 \pm 37.1 \mathrm{mmol} / \mathrm{L}$ and $164.37 \pm 22.3$ $\mathrm{mmol} / \mathrm{L}$, respectively. In contrast, $C$. dehaani had a high survival rate $(>80 \%)$, even in $513.3 \mathrm{mmol} / \mathrm{L} \mathrm{NaCl}$ solution (Fig. 1C), although we observed a few signs of damages, such as slowed movements, indicating that $C$. dehaani responds to ambient solutions differently compared to $H$. tridens and M. japonicus.Because $C$. dehaani showed high survival rates even in high concentrations of $\mathrm{NaCl}$ solutions, Profit analysis could not determine $\mathrm{LC}_{50}$ in this species.

To determine whether administration of some ambient minor ions besides $\mathrm{Na}^{+}$and $\mathrm{Cl}^{-}$restore survival rate of H. tridens and M. japonicus in $513.3 \mathrm{mmol} / \mathrm{L} \mathrm{NaCl}$ solution, $513.3 \mathrm{mmol} / \mathrm{L} \mathrm{NaCl}$ solution was supplemented with $27.4 \mathrm{mmol} / \mathrm{L} \mathrm{MgSO}_{4}, 25.2 \mathrm{mmol} / \mathrm{L} \mathrm{MgCl}_{2}, 9.9 \mathrm{mmol} / \mathrm{L} \mathrm{CaCl}_{2}$, and $10.7 \mathrm{mmol} / \mathrm{L} \mathrm{KCl}$ (the resultant solution was referred to as $513.3 \mathrm{mmol} / \mathrm{L} \mathrm{NaCl}+\mathrm{MMCK}$ solution) to replicate the ionic composition of artificial seawater, and H. tridens and M. japonicus were reared in this solution. The survival rate significantly increased and reached $100 \%$ in both species (Fig. 2A, B), indicating that $513.3 \mathrm{mmol} / \mathrm{L} \mathrm{NaCl}+\mathrm{MMCK}$ 
solution contains sufficient ambient minor ions for both species to survive in the presence of $513.3 \mathrm{mmol} / \mathrm{L}$ $\mathrm{NaCl}$. To investigate which ambient minor ions are required for survival,H. tridens and $M$. japonicus were reared in several kinds of bathing media of isosmotic condition as follows; $513.3 \mathrm{mmol} / \mathrm{L} \mathrm{NaCl}, 513.3 \mathrm{mmol} / \mathrm{L}$ $\mathrm{NaCl}+\mathrm{MMCK}$, and $513.3 \mathrm{mmol} / \mathrm{L} \mathrm{NaCl}+\mathrm{MMCK}$ minus any one of the four additional salts. The survival rate decreased in both species in the bathing medium lacking $\mathrm{KCl}$ (Fig. 2A, B), indicating that $\mathrm{K}^{+}$is indispensable for survival of both species in the presence of $513.3 \mathrm{mmol} / \mathrm{L} \mathrm{NaCl}$. To determine the specific role of $\mathrm{K}^{+}$, the $513.3 \mathrm{mmol} / \mathrm{L} \mathrm{NaCl}$ solution was supplemented only with $10.7 \mathrm{mmol} / \mathrm{L} \mathrm{KCl}$ (referred to as the $513.3 \mathrm{mmol} / \mathrm{L} \mathrm{NaCl}+\mathrm{K}$ solution), and $H$. tridens and M. japonicus were reared in this solution. The survival rate did not fully recover in both species in $513.3 \mathrm{mmol} / \mathrm{L} \mathrm{NaCl}+\mathrm{K}$ solution (Fig. 2C, D), suggesting that addition of $\mathrm{K}^{+}$alone is insufficient. Thus the $513.3 \mathrm{mmol} / \mathrm{L} \mathrm{NaCl}+\mathrm{K}$ solution was supplemented with either $25.5 \mathrm{mmol} / \mathrm{L} \mathrm{MgCl}_{2}$ or $9.9 \mathrm{mmol} / \mathrm{L} \mathrm{CaCl}_{2}$ and H. tridens and $M$. japonicus were reared in these solutions. Both $513.3 \mathrm{mmol} / \mathrm{L} \mathrm{NaCl}+\mathrm{K}+25.5 \mathrm{mmol} / \mathrm{L} \mathrm{MgCl}_{2}$ and $513.3 \mathrm{mmol} / \mathrm{L} \mathrm{NaCl}+\mathrm{K}+9.9 \mathrm{mmol} / \mathrm{L} \mathrm{CaCl}_{2}$ restored survival rate of both species (Fig. 2C, D), indicating that the presence of both $\mathrm{K}^{+}$and a divalent cation (either $\mathrm{Mg}^{2+}$ or $\mathrm{Ca}^{2+}$ ) is necessary and sufficient for the survival of $H$. tridens and M. japonicus .

Next step of the study was to examine the hemolymph ionic composition and osmotic concentration of these crabs, H. tridens , M. japonicus, and C. dehaani incubated in the $8.6 \mathrm{mmol} / \mathrm{L} \mathrm{NaCl}, 513.3 \mathrm{mmol} / \mathrm{L}$ $\mathrm{NaCl}$ supplemented with $25.5 \mathrm{mmol} / \mathrm{L} \mathrm{MgCl}_{2}, 9.9 \mathrm{mmol} / \mathrm{L} \mathrm{CaCl} 2$, and $10.7 \mathrm{mmol} / \mathrm{L} \mathrm{KCl}$ (referred to as $513.3 \mathrm{mmol} / \mathrm{L} \mathrm{NaCl}+\mathrm{MCK}$ solution), and $513.3 \mathrm{mmol} / \mathrm{L} \mathrm{NaCl}$ solution. Hemolymph $\mathrm{Na}^{+}, \mathrm{K}^{+}$, and osmotic concentrations were determined at $6 \mathrm{~h}$ after incubation. The hemolymph $\mathrm{Na}^{+}$concentration in both $H$. tridens and $M$. japonicus held in $513.3 \mathrm{mmol} / \mathrm{L} \mathrm{NaCl}$ solution was significantly higher compared to 513.3 $\mathrm{mmol} / \mathrm{L} \mathrm{NaCl}+\mathrm{MCK}$ solution (Fig. 3A, B). In addition, the hemolymph $\mathrm{K}^{+}$concentration in crabs held in $513.3 \mathrm{mmol} / \mathrm{L} \mathrm{NaCl}$ solution was significantly less compared to $513.3 \mathrm{mmol} / \mathrm{L} \mathrm{NaCl}+\mathrm{MCK}$ solution and was comparable to the hemolymph $\mathrm{K}^{+}$concentration in crabs held in $8.6 \mathrm{mmol} / \mathrm{L} \mathrm{NaCl}$ solution (Fig. 3D, E). Moreover, hemolymph osmotic concentration in $H$. tridens held in $513.3 \mathrm{mmol} / \mathrm{L} \mathrm{NaCl}$ solution was significantly higher compared to that in $513.3 \mathrm{mmol} / \mathrm{L} \mathrm{NaCl}+\mathrm{MCK}$ solution, but not in $M$. japonicus (Table 2 ). In contrast, differences in ionic compositions of bathing media did not change hemolymph $\mathrm{Na}^{+}, \mathrm{K}^{+}$, and osmotic concentrations in C. dehaani, which had a high survival rate in $513.3 \mathrm{mmol} / \mathrm{L} \mathrm{NaCl}$ solution (Fig. 3C, F; Table 2).

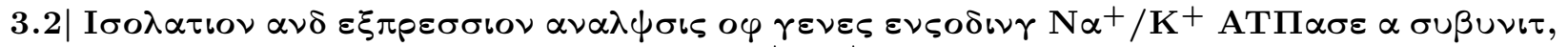

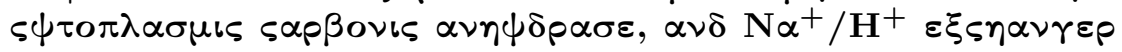

To analyze the possibility that changes in the expression of genes involved in $\mathrm{Na}^{+}$uptake disturbed hemolymph ionic composition and ultimately led to the death of crabs in rearing experiments, cDNA fragments of NKA $\alpha$ subunit, CAc, and NHE were amplified by PCR and isolated, and gene expression was analyzed in the most posterior gills of $H$. tridens, M. japonicus, and $C$. dehaani. The lengths of isolated cDNA fragments for the NKA $\alpha$ subunit, CAc, and NHE genes were 700, 300, and $800 \mathrm{bp}$, respectively. Sequencing results showed that the cDNA fragment sequences of these genes were highly similar to those in other crab species. The deduced amino acid sequences of the NKA $\alpha$ subunit of $H$. tridens, M. japonicus , and C. dehaani had 95\%, 95\%, and 94\% similarity, respectively, to that of C. maenas ; those of CAc of H. tridens, M. japonicus, and C. dehaani had $76 \%, 78 \%$, and $75 \%$ similarity, respectively, to that of C. maenas; and those of the NHE of H. tridens, M. japonicus, and C. dehaanihad $94 \%, 93 \%$, and $92 \%$ similarity, respectively, to that of C. maenas (Fig. 4A-C) (Towle et al., 1997; Serrano and Henry, 2008).

The expression of these genes in the most posterior gills of crabs held in the $8.6 \mathrm{mmol} / \mathrm{L} \mathrm{NaCl}, 513.3 \mathrm{mmol} / \mathrm{L}$ $\mathrm{NaCl}+\mathrm{MCK}$, and $513.3 \mathrm{mmol} / \mathrm{L} \mathrm{NaCl}$ solutions for $6 \mathrm{~h}$ were analyzed by Northern blotting. However, the expression levels of CAc gene was not sufficiently high in $M$. japonicus to be detected by Northern blotting; therefore, RNase protection assay was carried out to detect the expression of this gene in $M$. japonicus . These analyses revealed that the expression of all genes in the most posterior gills in $H$. tridens and $M$. japonicas was higher in $8.6 \mathrm{mmol} / \mathrm{L} \mathrm{NaCl}$ solution compared to $513.3 \mathrm{mmol} / \mathrm{L} \mathrm{NaCl}+\mathrm{MCK}$ solution except CAc in M. japonicus . Furthermore, the expression of all genes in the most posterior gills was also higher in $513.3 \mathrm{mmol} / \mathrm{L} \mathrm{NaCl}$ solution compared to $513.3 \mathrm{mmol} / \mathrm{L} \mathrm{NaCl}+\mathrm{MCK}$ solution as in $8.6 \mathrm{mmol} / \mathrm{L} \mathrm{NaCl}$ 
solution (Fig. 5). On the other hand, the expression of these genes was different in C. dehaani. The expression of genes encoding NKA $\alpha$ subunit was enhanced in $513.3 \mathrm{mmol} / \mathrm{L} \mathrm{NaCl}$ solution but was less drastic compared to $H$. tridens and $M$. japonicus. In addition, the expression of CAc gene was not induced in $513.3 \mathrm{mmol} / \mathrm{L} \mathrm{NaCl}$ solution but was in $8.6 \mathrm{mmol} / \mathrm{L} \mathrm{NaCl}$ solution. In contrast, the expression of NHE gene was enhanced in $513.3 \mathrm{mmol} / \mathrm{L} \mathrm{NaCl}$ solution but not in $8.6 \mathrm{mmol} / \mathrm{L} \mathrm{NaCl}$ solution (Fig. 5).

\section{3| Effects of carbonic anhydrase and $\mathrm{Na}^{+} / \mathrm{H}^{+}$exchanger inhibitors}

Increased expression of genes involved in $\mathrm{Na}^{+}$uptake could be a possible cause of the death of $H$. tridens and M. japonicus in $513.3 \mathrm{mmol} / \mathrm{L} \mathrm{NaCl}$ solution. To examine this possibility,H. tridens and M. japonicas were reared in $513.3 \mathrm{mmol} / \mathrm{L} \mathrm{NaCl}$ solution supplemented with acetazolamide or amiloride, an inhibitor of CA and NHE, respectively. Amiloride significantly increased the survival rate of $H$. tridens and M. japonicus, and acetazolamide increased the survival rate of $M$. japonicus reared in $513.3 \mathrm{mmol} / \mathrm{L} \mathrm{NaCl}$ solution (Fig. 6BD). The survival rate was also higher in $H$. tridens reared in $513.3 \mathrm{mmol} / \mathrm{L} \mathrm{NaCl}$ solution supplemented with acetazolamide compared to $513.3 \mathrm{mmol} / \mathrm{L} \mathrm{NaCl}$ solution, but the results were not statistically significant (Fig. 6A).

\section{$3.4 \mid$ Effects of ambient minor cations on survival and hemolymph composition of euryhaline crabs under hypo-osmotic conditions}

To investigate the effects of ambient minor cations on the survival of euryhaline crabs at low ambient salinity, $H$. tridens , M. japonicus, and C. dehaani were reared in $8.6 \mathrm{mmol} / \mathrm{L} \mathrm{NaCl}$ solution supplemented with $25.2 \mathrm{mmol} / \mathrm{L} \mathrm{MgCl}_{2}, 9.9 \mathrm{mmol} / \mathrm{L} \mathrm{CaCl}{ }_{2}$, and $10.7 \mathrm{mmol} / \mathrm{L} \mathrm{KCl}$ (referred to as $8.6 \mathrm{mmol} / \mathrm{L} \mathrm{NaCl}+\mathrm{MCK}$ solution), $8.6 \mathrm{mmol} / \mathrm{L} \mathrm{NaCl}$ solution, and $17.1 \mathrm{mmol} / \mathrm{L} \mathrm{NaCl}$ solution without additional salts. Additional salts did not have any effect on the survival of $H$. tridens and C. dehaani, showing $100 \%$ survival in both species (data not shown). In contrast, the survival rate considerably decreased in M. japonicus in $8.6 \mathrm{mmol} / \mathrm{L} \mathrm{NaCl}+\mathrm{MCK}$ solution (data not shown). Because some M. japonicus individuals still appeared intact in $8.6 \mathrm{mmol} / \mathrm{L} \mathrm{NaCl}+\mathrm{MCK}$ solution, further experiments were conducted using $4.3 \mathrm{mmol} / \mathrm{L} \mathrm{NaCl}, 4.3$ $\mathrm{mmol} / \mathrm{L} \mathrm{NaCl}$ supplemented with $30.5 \mathrm{mmol} / \mathrm{L} \mathrm{MgCl}_{2}, 11.7 \mathrm{mmol} / \mathrm{L} \mathrm{CaCl}_{2}$, and $13.4 \mathrm{mmol} / \mathrm{L} \mathrm{KCl}$ (referred to as $4.3 \mathrm{mmol} / \mathrm{L} \mathrm{NaCl}+1.2 \mathrm{MCK}$ solution), and $17.1 \mathrm{mmol} / \mathrm{L} \mathrm{NaCl}+1.2 \mathrm{MCK}$ solution. The survival rate of $\mathrm{H}$. tridens and C. dehaani was $100 \%$, but that of $M$. japonicus significantly decreased to $17 \%$ in 4.3 mmol/L NaCl+1.2 MCK solution (Fig. 7). A few M. japonicusindividuals survived in this solution but were moribund. In contrast, most $M$. japonicus individuals survived in $4.3 \mathrm{mmol} / \mathrm{L} \mathrm{NaCl}$ and $17.1 \mathrm{mmol} / \mathrm{L}$ $\mathrm{NaCl}+1.2 \mathrm{MCK}$ solution (Fig. 7B). These results indicated that higher concentrations of additional salts in combination with a lower $\mathrm{NaCl}$ concentration caused high mortality in $M$. japonicus in $4.3 \mathrm{mmol} / \mathrm{L} \mathrm{NaCl}+1.2$ MCK solution.

To examine which minor cations have lethal effect on $M$. japonicus, $30.5 \mathrm{mmol} / \mathrm{L} \mathrm{MgCl}_{2}$ and $11.7 \mathrm{mmol} / \mathrm{L}$ $\mathrm{CaCl}_{2}(1.2 \mathrm{MC})$ and $13.4 \mathrm{mmol} / \mathrm{L} \mathrm{KCl}(1.2 \mathrm{~K})$ were added to $4.3 \mathrm{mmol} / \mathrm{L} \mathrm{NaCl}$ solution separately. In $M$. japonicus reared in $4.3 \mathrm{mmol} / \mathrm{L} \mathrm{NaCl}$ solution supplemented with $13.4 \mathrm{mmol} / \mathrm{L} \mathrm{KCl}$ (referred to as 4.3 $\mathrm{mmol} / \mathrm{L} \mathrm{NaCl}+1.2 \mathrm{~K}$ solution), the survival rate significantly decreased to a comparable level as that in 4.3 $\mathrm{mmol} / \mathrm{L} \mathrm{NaCl}+1.2 \mathrm{MCK}$ solution (Fig. 7D). Even after diluting $\mathrm{KCl}$ to $2.7 \mathrm{mmol} / \mathrm{L}$ (almost one-fourth of the concentration in seawater), the survival rate did not hardly recover (Fig. 7E), indicating that $\mathrm{K}^{+}$accounts for the lethality in $4.3 \mathrm{mmol} / \mathrm{L} \mathrm{NaCl}+1.2 \mathrm{MCK}$ solution. In contrast, supplementation of $4.3 \mathrm{mmol} / \mathrm{L} \mathrm{NaCl}$ with $30.5 \mathrm{mmol} / \mathrm{L} \mathrm{MgCl}_{2}$ and $11.7 \mathrm{mmol} / \mathrm{L} \mathrm{CaCl}_{2}$ did not have a lethal effect on $M$. japonicus ; instead, these divalent cations attenuated the lethal effect of $\mathrm{K}^{+} 15 \mathrm{~h}$ after initiation of rearing, although it did not block the lethal effect at all $48 \mathrm{~h}$ after initiation of rearing (Fig. 7D, F).

Possible effects of ambient minor cations under hypo-osmotic conditions on hemolymph ionic composition and osmotic concentration were examined in H. tridens, M. japonicus, and C. dehaani. They were incubated in the $4.3 \mathrm{mmol} / \mathrm{L} \mathrm{NaCl}$ and $4.3 \mathrm{mmol} / \mathrm{L} \mathrm{NaCl}+1.2 \mathrm{MCK}$ solutions, and hemolymph $\mathrm{Na}^{+}, \mathrm{K}^{+}$, and osmotic concentrations were determined $6 \mathrm{~h}$ after incubation. There were no significant differences in the hemolymph $\mathrm{Na}^{+}$concentration between crabs incubated in $4.3 \mathrm{mmol} / \mathrm{L} \mathrm{NaCl}$ and $4.3 \mathrm{mmol} / \mathrm{L} \mathrm{NaCl}+1.2 \mathrm{MCK}$ solutions in all three species (Fig. $8 \mathrm{~A}-\mathrm{C}$ ). In contrast, the hemolymph $\mathrm{K}^{+}$concentration in crabs incubated in 4.3 
mmol/L NaCl+1.2 MCK solution was significantly higher compared to $4.3 \mathrm{mmol} / \mathrm{L} \mathrm{NaCl}$ solution in $H$. tridens and M. japonicusbut not in C. dehaani (Fig. 8E-G). Moreover, addition of minor cations increased osmotic concentration significantly in M. japonicus, but not in H. tridens and M. japonicus (Table 3). Additional experiments were conducted to know specific role of $\mathrm{K}^{+}$on the hemolymph ionic composition in M. japonicus. Administration of $\mathrm{KCl}$ increased the hemolymph $\mathrm{K}^{+}$concentration as combined administration of $\mathrm{MgCl}_{2}, \mathrm{CaCl}_{2}$, and $\mathrm{KCl}$ (Fig. $8 \mathrm{H}$ ).

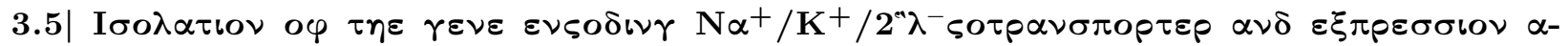
$\nu \alpha \lambda \psi \sigma i s$ o

To analyze the possibility that changes in the expression of genes involved in $\mathrm{K}^{+}$transport disturbed hemolymph $\mathrm{K}^{+}$concentration and ultimately led to the death of $M$. japonicus in $4.3 \mathrm{mmol} / \mathrm{L} \mathrm{NaCl}+1.2$ MCK solution, cDNA fragment of NKCC was amplified by PCR and isolated, and gene expression of it and NKA $\alpha$ subunit was analyzed in the most posterior gills of $H$. tridens, $M$. japonicus, and $C$. dehaani. The deduced amino acid sequence of NKCC of $H$. tridens , $M$. japonicus , and $C$. dehaani had $81 \%, 79 \%$, and $77 \%$ similarity to that of $C$. maenas (Fig. 4D). Northern blotting revealed that NKA $\alpha$ subunit expression in the most posterior gills of crabs incubated in $4.3 \mathrm{mmol} / \mathrm{L} \mathrm{NaCl}+1.2 \mathrm{MCK}$ solution for $6 \mathrm{~h}$ decreased compared to $4.3 \mathrm{mmol} / \mathrm{L} \mathrm{NaCl}$ solution in all three species. In H. tridens and M. japonicus, NKCC expression also decreased in the presence of ambient minor cations, although the expression was relatively low (Fig. 9). In contrast, NKCC expression in C. dehaani was less affected by ambient minor cations (Fig. 9).

\section{4| DISCUSSION}

In this study, three species of euryhaline crabs, H. tridens, $M$. japonicus, and $C$. dehaani were used. Habitats of $H$. tridens and $M$. japonicus are restricted within estuaries, but $C$. dehaani is a species which invaded more upstream regions and is adaptive to fresh water (Irawan and Kijima, 1993; Kobayashi, 2000). These species belong to three different families: Varunidae (H. tridens ), Ocypodidae (M. japonicus ), and Sesarmidae ( $C$. dehaani ), although $H$. tridens and $C$. dehaani belong to the same superfamily, Grapsoidea. The different responses to environmental water of these species are possibly due to the differences in the microenvironment of their habitats or phylogeny.

\section{1| Effect of ambient minor cations in seawater on the survival of euryhaline crabs}

It has been reported that not only salinity but also ionic composition of the environment significantly affects the survival of euryhaline crustaceans. For example, the mortality of the euryhaline prawn $P$. mondon reaches $100 \%$ during the first $48 \mathrm{~h}$ in $0.17 \% \mathrm{NaCl}$ solution, although it remains low in diluted artificial seawater of the same salinity (Cawthorne et al., 1983), indicating that some ambient minor ions, besides $\mathrm{Na}^{+}$and $\mathrm{Cl}^{-}$, are essential for its survival. In addition, analysis of ionic profiles of inland well water for cultivation of prawns shows that the presence of $\mathrm{K}^{+}, \mathrm{Mg}^{2+}$, and $\mathrm{SO}_{4}{ }^{2-}$ increases the survival rate of euryhaline prawns L. vannamei and M. latisulcatus (Saoud et al., 2003; Davis et al., 2005; Prangnell and Fotedar, 2005, 2006; Roy et al., 2007). Furthermore, removal of either $\mathrm{Ca}^{2+}$ or $\mathrm{Mg}^{2+}$ or both, but not $\mathrm{K}^{+}$, from seawater causes lethal damage to the shore crab C. maenas, showing that both divalent cations, but not $\mathrm{K}^{+}$, are required for its survival (Lovett et al., 2006a).

This study revealed that both $H$. tridens and $M$. japonicuscan survive even in $8.6 \mathrm{mmol} / \mathrm{L} \mathrm{NaCl}$ solution but not in $513.3 \mathrm{mmol} / \mathrm{L} \mathrm{NaCl}$ solution. The high mortality of $H$. tridens and M. japonicus in $513.3 \mathrm{mmol} / \mathrm{L}$ $\mathrm{NaCl}$ solution indicates some ambient minor ions besides $\mathrm{Na}^{+}$and $\mathrm{Cl}^{-}$are required for these crabs to survive under isosmotic condition. For complete recovery of the survival rate in $513.3 \mathrm{mmol} / \mathrm{L} \mathrm{NaCl}$ solution, both $\mathrm{K}^{+}$and divalent cations, either $\mathrm{Mg}^{2+}$ or $\mathrm{Ca}^{2+}$, are required (Fig. 2). In addition, the required ambient minor ions for both $H$. tridensand $M$. japonicus are different compared to other euryhaline crustaceans previously examined: (1) $\mathrm{SO}_{4}{ }^{2-}$ is not needed for survival of $H$. tridens and $M$. japonicus unlike $L$. vannamei (Saoud et al., 2003), (2) $\mathrm{K}^{+}$and either $\mathrm{Mg}^{2+}$ or $\mathrm{Ca}^{2+}$ are essential for bothH. tridens and M. japonicus, although both $\mathrm{Mg}^{2+}$ and $\mathrm{Ca}^{2+}$, but not $\mathrm{K}^{+}$, are required for C. maenas (Lovett et al., 2006a), and (3) while P. mondon cannot survive $48 \mathrm{~h}$ in $0.17 \% \mathrm{NaCl}$ solution (Cawthorne et al., 1983), both H. tridens and M. japonicus can survive in $\mathrm{NaCl}$ solution with similar salinity $(32.1 \mathrm{mmol} / \mathrm{L}$, corresponding to $0.19 \%)$. These data show that 
the required minor ions for survival differ among species of euryhaline crustaceans, and the osmotic condition itself in which the ambient minor ions are functioning also differ, respectively. This difference might, in turn, reflect the difference between the microenvironments of their habitats and/or phylogeny. On the other hand, C. dehaani has a significantly high survival rate, even in $513.3 \mathrm{mmol} / \mathrm{L} \mathrm{NaCl}$ solution, in striking contrast to H. tridens and M. japonicas (Fig. 1). C. dehaani is more adaptive to lower salinity compared to H. tridens and M. japonicus (Irawan and Kijima, 1993), which would account for the robustness of this species in 513.3 $\mathrm{mmol} / \mathrm{L} \mathrm{NaCl}$ solution.

\section{2| Role of ambient minor cations under isosmotic conditions with seawater}

Under hypo-osmotic conditions, euryhaline crustaceans incorporate ambient ions, mainly $\mathrm{Na}^{+}$and $\mathrm{Cl}^{-}$, actively through chloride cells in the gills to maintain their hemolymph osmolality higher compared to the environment. Chloride cells in the posterior gills play a prominent role in the ionic regulation of hemolymph, and NKA, CAc, and NHE expressed in chloride cells are required to incorporate $\mathrm{Na}^{+}$from environmental water to hemolymph. NKA is distributed in the basolateral membrane of chloride cells, which transports $\mathrm{Na}^{+}$from the cytoplasm to the hemolymph and keeps the intracellular $\mathrm{Na}^{+}$concentration relatively low, generating driving force of $\mathrm{Na}^{+}$uptake. CAc in chloride cells catalyzes the formation of $\mathrm{H}^{+}$and $\mathrm{HCO}_{3}{ }^{-}$ from $\mathrm{H}_{2} \mathrm{O}$ and $\mathrm{CO}_{2}$, and the derived $\mathrm{H}^{+}$supports $\mathrm{Na}^{+}$uptake through activation of NHE located in the apical membrane (Freire et al., 2008; Charmantier et al., 2009; Henry et al., 2012; Griffith, 2017). In addition, the expression of genes encoding NKA, CAc, and NHE in euryhaline crabs increases under hypo-osmotic conditions (Lucu and Flik, 1999; Henry et al., 2003; Lucu and Towle, 2003; Lovett et al., 2006b; Liu et al., 2015; Pan et al., 2016). This study revealed that the expression of these genes was also enhanced in $H$. tridens and M. japonicus under hypo-osmotic conditions ( $8.6 \mathrm{mmol} / \mathrm{L} \mathrm{NaCl}$ solution) (Fig. 5), consistent with previous studies. In addition, the expression of these genes in posterior gills also increased in both species in $513.3 \mathrm{mmol} / \mathrm{L} \mathrm{NaCl}$ solution as in $8.6 \mathrm{mmol} / \mathrm{L} \mathrm{NaCl}$ solution, strongly indicating that ambient minor cations decrease the expression of these genes under isosmotic conditions with seawater. The enhanced expression of these genes could account for the increased $\mathrm{Na}^{+}$concentration, and concomitant with decreased $\mathrm{K}^{+}$concentration, increased $\mathrm{Na}^{+} / \mathrm{K}^{+}$ratio in hemolymph in $513.3 \mathrm{mmol} / \mathrm{L} \mathrm{NaCl}$ solution. An imbalance between $\mathrm{Na}^{+}$and $\mathrm{K}^{+}$concentrations in hemolymph can cause an increase in the mortality rate in crustaceans (Sowers et al., 2006). Thus the increased expression of the genes encoding NKA, CAc, and NHE in the most posterior gills might be the cause of death of $H$. tridens and $M$. japonicus reared in $513.3 \mathrm{mmol} / \mathrm{L} \mathrm{NaCl}$ solution through an increased $\mathrm{Na}^{+} / \mathrm{K}^{+}$ratio. The following findings support this view: (1) administration of acetazolamide and amiloride, inhibitors of CA and NHE, respectively, increased the survival rate of $H$. tridens and M. japonicusin $513.3 \mathrm{mmol} / \mathrm{L} \mathrm{NaCl}$ solution (Fig. 6), and (2) incubation of C. dehaani in 513.3 $\mathrm{mmol} / \mathrm{L} \mathrm{NaCl}$ solution, showing a high survival rate compared to H. tridens and M. japonicus, induced only limited increase of the expression of NKA $\alpha$ subunit and CAc and does not increase the $\mathrm{Na}^{+} / \mathrm{K}^{+}$ratio (Fig. $3)$.

It has been reported that the ambient minor cations in seawater are indispensable for the survival of euryhaline crustaceans. However, the physiological and ecological role of these ambient minor cations in euryhaline crustaceans is not completely understood. $\mathrm{Mg}^{2+}$ is involved in regulation of more than 300 enzymes, including NKA (Apell et al., 2017). In fact, activity of NKA in gills of crab is modulated by ambient $\mathrm{Mg}^{2+}$ (Masui et al., 2005, 2009; Antunes et al., 2017). Moreover, $\mathrm{Ca}^{2+}$ plays an important role in various biological processes, particularly in stabilizing biological membranes, increasing the tightness of intracellular tight junctions, and thereby controlling ion permeability across the gill epithelium in fish (McDonald et al., 1983; McDonald and Milligan, 1998). Lowering the concentration of ambient $\mathrm{Ca}^{2+}$ reduces hemolymph $\mathrm{Na}^{+}$concentration, irrespective of environmental $\mathrm{pH}$ in crayfish Cherax destructor (Ellis and Morris, 1995). In addition, when ambient $\mathrm{pH}$ is low, decreased ambient $\mathrm{Ca}^{2+}$ concentration reduces plasma or hemolymph $\mathrm{Na}^{+}$concentration in teleost species, Salmo gairdneri and Oryzias latipes, and crustaceans, Daphnia magna and D. middendorffiana, and leads to increased mortality (Jozuka and Adachi, 1979; McDonald et al., 1980; Haves et al., 1984). In this study, however, hemolymph $\mathrm{Na}^{+}$concentrations in $513.3 \mathrm{mmol} / \mathrm{L} \mathrm{NaCl}$ solution increased both in $H$. tridens and M. japonicus compared to that in $513.3 \mathrm{mmol} / \mathrm{L} \mathrm{NaCl}+\mathrm{MCK}$ solution (Fig. 3). This suggests that the lethality in the $513.3 \mathrm{mmol} / \mathrm{L} \mathrm{NaCl}$ solution was not because of an inhibition of 
NKA by removal of $\mathrm{Mg}^{2+}$. In addition, we showed that the role of $\mathrm{Ca}^{2+}$ for survival of $H$. tridens and $M$. japonicus was substitutable by $\mathrm{Mg}^{2+}$ (Fig. 2). Furthermore, both these divalent cations could not overcome the lethality caused by removal of $\mathrm{K}^{+}$(Fig. 2), which is a striking contrast toOryzias latipes, in which only the addition of $\mathrm{Ca}^{2+}$ increases their survival rate in low $\mathrm{pH}$ conditions (Jozuka and Adachi, 1979). These results strongly suggest that minor cations have different roles on these species from those described above, although it is possible that cell membrane integrity and cell junction formation in gills would also be affected by the $513.3 \mathrm{mmol} / \mathrm{L} \mathrm{NaCl}$ solution also in these species.

This study suggests that ambient minor cations regulate the expression of specific genes in the gills, thereby affecting ion transport across the gills and hemolymph ionic composition. It might be necessary for euryhaline crustaceans inhabiting estuaries to sense subtle changes of ambient minor cation concentrations to adapt environmental salinity fluctuation. Future studies should be addressed to know whether these ambient minor cations directly affect gene expression in the gills. A comprehensive identification of the genes that are involved in ion transport and whose expression is regulated by ambient minor cations is also an important challenge.

\section{3| Role of ambient minor cations under hypo-osmotic conditions}

This study revealed that ambient minor cations, especially $\mathrm{K}^{+}$, caused lethal damage to $M$. japonicus under hypo-osmotic conditions $(4.3 \mathrm{mmol} / \mathrm{L} \mathrm{NaCl}$ solution) (Fig. 7), showing a striking contrast to isosmotic conditions (Fig. 2B). Ambient $\mathrm{K}^{+}$was essential in isosmotic conditions, but harmful in hypo-osmotic condition. Thus it appears that ambient $\mathrm{K}^{+}$has an opposite influence on the survival of M. japonicus in an osmotic condition-dependent manner. The hemolymph $\mathrm{K}^{+}$concentration in $M$. japonicusincreased when the crabs were bathed in $4.3 \mathrm{mmol} / \mathrm{L} \mathrm{NaCl}+1.2 \mathrm{MCK}$ solution compared to $4.3 \mathrm{mmol} / \mathrm{L} \mathrm{NaCl}$ solution (Fig. 8F). Because the hemolymph $\mathrm{Na}^{+}$concentration is the same in both solutions, the $\mathrm{Na}^{+} / \mathrm{K}^{+}$ratio in hemolymph decreases in $4.3 \mathrm{mmol} / \mathrm{L} \mathrm{NaCl}+1.2 \mathrm{MCK}$ solution. It is possible to assume that a decreased $\mathrm{Na}^{+} / \mathrm{K}^{+}$ratio accounts for the lethality in M. japonicus. NKA and NKCC have been identified as molecules involved in $\mathrm{K}^{+}$transport in chloride cells in the gills of euryhaline crustaceans (Freire et al., 2008; Charmantier et al., 2009; Henry et al., 2012; Griffith, 2017). NKA transports $\mathrm{K}^{+}$from hemolymph to the cytoplasm in the opposite direction to $\mathrm{Na}^{+}$. On the other hand, NKCC is distributed in the apical membrane of chloride cells and incorporates $\mathrm{K}^{+}$from the environment into cells, concomitant with $\mathrm{Na}^{+}$and $\mathrm{Cl}^{-}$. Northern blotting showed that NKA $\alpha$ subunit expression was attenuated in all three species in the presence of ambient minor cations under hypo-osmotic conditions (Fig. 9). This decreased NKA $\alpha$ subunit expression might decrease $\mathrm{K}^{+}$transport from hemolymph to chloride cells, possibly resulting in increased hemolymph $\mathrm{K}^{+}$concentration. However, it is unclear whether this downregulation of NKA $\alpha$ subunit gene accounts for the increased hemolymph $\mathrm{K}^{+}$concentration in $M$. japonicus, since this gene was also attenuated in C. dehaani in which ambient minor cations did not affect the hemolymph $\mathrm{K}^{+}$concentration (Fig. 8G). In addition, NKCC gene expression also decreases in the presence of ambient minor cations under hypoosmotic conditions in both $H$. tridensand $M$. japonicus, indicating that NKCC does not contribute to increased hemolymph $\mathrm{K}^{+}$concentration, because decreased expression of this gene should lead to decreased hemolymph $\mathrm{K}^{+}$concentration. It is possible that unidentified transporters and/or channels involved in $\mathrm{K}^{+}$ transport are activated by ambient minor cations to accelerate $\mathrm{K}^{+}$uptake under hypo-osmotic conditions.

Interestingly, in $H$. tridens, ambient minor cations increased the hemolymph $\mathrm{K}^{+}$concentration in hypoosmotic condition (Fig. 8E) although they caused no mortality (Fig. 7A). Therefore, it is possible that H. tridens is more tolerant to elevated $\mathrm{K}^{+}$concentrations and low $\mathrm{Na}^{+} / \mathrm{K}^{+}$ratio in hemolymph compared to $M$. japonicus. It is noteworthy that the average hemolymph $\mathrm{K}^{+}$concentration in $M$. japonicus bathed in $513.3 \mathrm{mmol} / \mathrm{L} \mathrm{NaCl}+1.2 \mathrm{MCK}$ is $15.3 \pm 1.28 \mathrm{mmol} / \mathrm{L}$, which is significantly higher than the nominal $\mathrm{K}^{+}$concentration in bathing media $(13.4 \mathrm{mmol} / \mathrm{L})$, although the average hemolymph $\mathrm{K}^{+}$concentration in H. tridens is $11.5 \pm 1.79 \mathrm{mmol} / \mathrm{L}$, still less than the nominal $\mathrm{K}^{+}$concentration in bathing media. Thus ambient minor cations may affect the $\mathrm{K}^{+}$transport system differently in $H$. tridens and $M$. japonicus. Another possibility is that some unidentified damage occurs only in $M$. japonicus but not in $H$. tridens in the presence of ambient minor cations under hypo-osmotic conditions. The fact that osmotic concentration 
increased significantly in the presence of minor cations in $M$. japonicus but not in $H$. tridens (Table 3 ) suggest that transport of some ions other than $\mathrm{Na}^{+}$and $\mathrm{K}^{+}$was affected only in $M$. japonicus. The mechanism by which ambient minor cations cause mortality to $M$. japonicus under hypo-osmotic conditions should be investigated in the future.

\subsection{Distinct response of $C$. dehaani to ambient minor cations}

The response of $C$. dehaani to ambient minor cations is different from that of H. tridens and M. japonicus. First, under isosmotic conditions, the decrease of survival rate of $C$. dehaaniin $513.3 \mathrm{mmol} / \mathrm{L} \mathrm{NaCl}$ was less drastic (Fig. 1). Consistent with this result, there was no significant difference in hemolymph $\mathrm{Na}^{+}$and $\mathrm{K}^{+}$ concentrations between crabs bathed in $513.3 \mathrm{mmol} / \mathrm{L} \mathrm{NaCl}$ and $513.3 \mathrm{mmol} / \mathrm{L} \mathrm{NaCl}+\mathrm{MCK}$ solutions (Fig. 3C, F). In addition, NKA expression was enhanced but less drastic compared to H. tridens and M. japonicus , and CAc expression was not activated in $513.3 \mathrm{mmol} / \mathrm{L} \mathrm{NaCl}$ solution (Fig. 5). Furthermore, ambient minor cations did not affect the survival rate (Fig. 7C) and hemolymph $\mathrm{Na}^{+}$and $\mathrm{K}^{+}$concentrations under hypo-osmotic conditions (Fig. 8C, G). These results strongly indicate that $C$. dehaani is less susceptive to ambient minor cations compared to H. tridens and M. japonicus.Compared to H. tridens and M. japonicus , C. dehaaniis adaptive to fresh water and habitats of this species is not restricted within estuaries but extends more upstream regions (Irawan and Kijima, 1993; Kobayashi, 2000). Susceptibility to ambient minor cations would be less adaptive for such species and lost in $C$. dehaani. Alternatively, the difference of sensitivity to ambient minor cations is due to phylogenetic difference of these species. Comparative studies using other fresh water-adaptive crabs, such as Eriocheir japonica and E. sinensis (Varunidae), will elucidate the relationship between sensitivity to ambient minor cations and adaptation to fresh water.

\section{5| CONCLUSION}

Ambient minor cations regulate the expression patterns of specific genes involved in ion transport and thereby affect the hemolymph ionic composition and, ultimately, the survival of $H$. tridens and $M$. japonicus. In contrast, in C. dehaani, which lives in more upstream region, ambient minor cations hardly affect the hemolymph ionic composition, likely because of less susceptibility of gene expression to ambient minor cations. The different response to ambient minor cations between euryhaline species could be due to the difference in the microenvironment of their habitats or phylogenetic difference.

\section{References}

Antunes CD, Lucena MN, Garçon DP, Leone FA, McNamara JC (2017) Low salinity-induced alterations in epithelial ultrastructure, $\mathrm{Na}^{+} / \mathrm{K}^{+}$-ATPase immunolocalization and enzyme kinetic characteristics in the gills of the thinstripe hermit crab, Clibanarius vittatus (Anomura, Diogenidae). J Exp Zool A Ecol Integr Physiol, 327, 380-397.

Apell HJ, Hitzler T, Schreiber G (2017) Modulation of the Na,K-ATPase by magnesium ions. Biochem, 56,1005-1016.

Burnett LE, Towle DW (1990) Sodium ion uptake by perfused gills of the blue crab Callinectes sapidus: Effects of ouabain and amiloride. J Exp Biol, 149, 293-305.

Cawthorne DF, Beard T, Davenport J, Wickins JF (1983) Responses of juvenile Penaeus monodon Fabricius to natural and artificial sea waters of low salinity. Aquaculture, 32, 165-174.

Charmantier G, Charmantier-Daures M, Towle D (2009) Osmotic and ionic regulation in aquatic arthropods. In "Osmotic and Ionic Regulation: Cells and Animals" Ed by DH Evans, CRC Press, Boca Raton, pp 165-230.

Davis DA, Boyd CE, Rouse DB, Saoud IP (2005) Effects of potassium, magnesium and age on growth and survival of Litopenaeus vannameipost-larvae reared in inland low salinity well waters in west Alabama. J World Aquac Soc, 36, 403-406.

Ellis BA, Morris S (1995) Effects of extreme pH on the physiology of the Australian 'yabby' Cherax destructor: acute and chronic changes in haemolymph oxygen levels, oxygen consumption and metabolic levels. J 
Exp Biol, 198. 395-407.

Freire CA, Onken H, McNamara JC (2008) A structure-function analysis of ion transport in crustacean gills and excretory organs. Comp Biochem Physiol A Mol Integr Physiol, 151, 272-304.

Genovese G, Ortiz N, Urcola MR, Luquet CM (2005) Possible role of carbonic anhydrase, V-H(+)ATPase, and $\mathrm{Cl}(-) / \mathrm{HCO} 3-$ exchanger in electrogenic ion transport across the gills of the euryhaline crabChasmagnathus granulatus. Comp Biochem Physiol A Mol Integr Physiol, 142, 362-369.

Griffith MB (2017) Toxicological perspective on the osmoregulation and ionoregulation physiology of major ions by freshwater animals: teleost fish, crustacea, aquatic insects, and Mollusca. Environ Toxicol Chem, 36, 576-600.

Havas M, Hutchinson TC, Likens GE (1984) Effect of low pH on sodium regulation in two species of Daphnia . Can J Zool, 62, 1965-1970.

Henry RP, Gehnrich S, Weihrauch D, Towle DW (2003) Salinity-mediated carbonic anhydrase induction in the gills of the euryhaline green crab,Carcinus maenas. Comp Biochem Physiol A Mol Integr Physiol, 136, 243-258.

Henry RP, Lucu C, Onken H, Weihrauch D (2012) Multiple functions of the crustacean gill: osmotic/ionic regulation, acid-base balance, ammonia excretion, and bioaccumulation of toxic metals. Front Physiol, 3, $1-33$.

Irawan B, Kijima A (1993) Difference of salinity requirements among the three estuarine crab species, Chiromantes dehaani, Helice tridens and H. japonica (Brachyura: Grapsidae). Tohoku J Agricult Res, 44, 39-47.

Jozuka K, Adachi H (1979) Eevironmental physiology on the pH tolerance of teleost. II: Blood properties of medaka, Oryzias latipes, exposed to low pH environment. Annot Zool Jpn, 52, 107-113.

Kobayashi S (2000) Distribution pattern and ecology of brachyuran crabs in the riverine environment: their significance in the ecosystem and present condition. Ecol Civil Eng, 3, 113-130. (in Japanese with English abstract)

Lignot J-H, Charmantier G (2015) Osmoregulation and excretion. In "Physiology (Natural History of the Crustacea, Vol 4)" Ed by ES Chang, M Thiel, Oxford University Press, New York, pp 249-284.

Liu M, Liu S, Hu Y, Pan L (2015) Cloning and expression analysis of two carbonic anhydrase genes in white shrimp Litopenaeus vannamei, induced by $\mathrm{pH}$ and salinity stresses. Aquaculture, 448, 391-400.

Lovett DL, Tanner CA, Glomski K, Ricart TM, Borst DW (2006a) The effect of seawater composition and osmolality on hemolymph levels of methyl farnesoate in the green crab Carcinus maenas. Comp Biochem Physiol A Mol Integr Physiol, 143, 67-77.

Lovett DL, Verzi MP, Burgents JE, Tanner CA, Glomski K, Lee JJ, Towle DW (2006b) Expression profiles of $\mathrm{Na}^{+}, \mathrm{K}^{+}$-ATPase during acute and chronic hypo-osmotic stress in the blue crab Callinectes sapidus. Biol Bull, 211, 58-65.

Lucu Č, Flik G (1999) $\mathrm{Na}^{+}-\mathrm{K}^{+}$-ATPase and $\mathrm{Na}^{+} / \mathrm{Ca}^{2+}$ exchange activities in gills of hyperregulating Carcinus maenas. Am J Physiol, 276, R490-499.

Lucu Č, Towle DW (2003) $\mathrm{Na}^{+}+\mathrm{K}^{+}$-ATPasein gills of aquatic crustacea. Comp Biochem Physiol A Mol Integr Physiol, 135, 195-214.

Lv J, Liu P, Wang Y, Gao B, Chen P, Li J (2013) Transcriptome analysis of Portunus trituberculatus in response to salinity stress provides insights into the molecular basis of osmoregulation. PLoS One, 8, e82155. 
Masui DC, Furriel RP, Silva EC, Mantelatto FL, McNamara JC, Barrabin H, Scofano HM, Fontes CF, Leone FA (2005) Gill microsomal (Na+,K+)-ATPase from the blue crab Callinectes danae: Interactions at cationic sites. Int J Biochem Cell Biol, 37, 2521-2535.

Masui DC, Mantelatto FL, McNamara JC, Furriel RP, Leone FA (2009) Na+, K+-ATPase activity in gill microsomes from the blue crab, Callinectes danae, acclimated to low salinity: novel perspectives on ammonia excretion. Comp Biochem Physiol A Mol Integr Physiol, 153, 141-148.

McDonald DG, Hobe H, Wood CM (1980) The influence of calcium on the physiological responses of the rainbow trout, Salmo gairdneri, to low environmental pH. J Exp Biol, 88, 109-131.

McDonald DG, Walker RL, Wilkes, PRH (1983) The interaction of environmental calcium and low pH on the physiology of the rainbow trout,Salmo gairdneri : II. Branchial ionoregulatory mechanisms. J Exp Biol, $102,141-155$.

McDonald DG, Milligan CL (1988). Sodium transport in the brook trout,Salvelinus fontinalis : effects of prolonged low pH exposure in the presence and absence of aluminum. Can J Fish Aquat Sci, 45, 1606-1613.

Pan L, Hu D, Liu M, Hu Y, Liu S (2016) Molecular cloning and sequence analysis of two carbonic anhydrase in the swimming crabPortunus trituberculatus and its expression in response to salinity and $\mathrm{pH}$ stress. Gene, $576,347-357$.

Prangnell DI, Fotedar R (2005) The Effect of Potassium Concentration in Inland Saline Water on the Growth and Survival of the Western King Shrimp, Penaeus latisulcatus Kishinouye, 1896. J Appl Aquac, 17, 19-34.

Prangnell DI, Fotedar R (2006) Effect of sudden salinity change on Penaeus latisulcatus Kishinouye osmoregulation, ionoregulation and condition in inland saline water and potassium-fortified inland saline water. Comp Biochem Physiol A Mol Integr Physiol, 145, 449-457.

Roy LA, Davis DA, Saoud IP, Henry RP (2007) Effects of varying levels of aqueous potassium and magnesium on survival, growth, and respiration of the Pacific white shrimp, Litopenaeus vannamei, reared in low salinity waters. Aquaculture, 262, 461-469.

Saoud IP, Davis DA, Rouse DB (2003) Suitability studies of inland well waters for Litopenaeus vannamei culture. Aquaculture, 217, 373-383.

Serrano L, Henry RP (2008) Differential expression and induction of two carbonic anhydrase isoforms in the gills of the euryhaline green crab, Carcinus maenas, in response to low salinity. Comp Biochem Physiol D Genomics Proteomics, 3, 186-93.

Sowers AD, Young SP, Grosell M, Browdy CL, Tomasso JR (2006) Hemolymph osmolality and cation concentrations in Litopenaeus vannamei during exposure to artificial sea salt or a mixed-ion solution: relationship to potassium flux. Comp Biochem Physiol A Mol Integr Physiol, 145, 176-180.

Sugiyama Y, Ota Y, Hara M, Inoue S (2001) Osmotic stress up-regulates aquaporin-3 gene expression in cultured human keratinocytes. Biochim Biophys Acta, 1522, 82-88.

Towle DW, Rushton ME, Heidysch D, Magnani JJ, Rose MJ, Amstutz A, Jordan MK, Shearer DW, Wu WS (1997) Sodium/proton antiporter in the euryhaline crab Carcinus maenas : molecular cloning, expression and tissue distribution. J Exp Biol, 200, 1003-1014.

Towle DW, Henry RP, Terwilliger NB (2011) Microarray-detected changes in gene expression in gills of green crabs (Carcinus maenas) upon dilution of environmental salinity. Comp Biochem Physiol Part D Genomics Proteomics, 6, 115-125.

Tresguerres M, Parks SK, Sabatini SE, Goss GG, Luquet CM (2008) Regulation of ion transport by pH and $\left[\mathrm{HCO}_{3}{ }^{-}\right]$in isolated gills of the crab Neohelice (Chasmagnathus)granulata. Am J Physiol Regul Integr Comp Physiol, 294, R1033-1043. 
Yamaguchi M, Takahashi H, Wakahara M (2000) Erythropoiesis and unexpected expression pattern of globin genes in the salamander Hynobius retardatus. Dev Genes Evol, 210, 180-189.

Yamaguchi M, Wakahara M (2001) Contribution of ventral and dorsal mesoderm to primitive and definitive erythropoiesis in the salamander Hynobius retardatus. Dev Biol, 230, 204-216.

Zhu C, Dong S, Wang F, Huang G (2004) Effects of Na/K ratio in seawater on growth and energy budget of juvenile Litopenaeus vannamei.Aquaculture, 234, 485-496.

TABLE 1. The composition of bathing media used in this study. Concentrations of dissolved salts are shown by mmol/L and measured osmotic concentration are given by $\mathrm{mOsm} / \mathrm{kg}$. $513.3 \mathrm{mmol} / \mathrm{L} \mathrm{NaCl}$ is corresponds to $3 \% \mathrm{NaCl}$. N. D. means not determined.

\section{Hosted file}

image1.emf available at https://authorea.com/users/351272/articles/475958-hemolymphcomposition-gene-expressions-in-the-gills-and-thus-the-survival-of-euryhaline-crabsare-controlled-by-ambient-minor-cations-according-to-osmotic-condition-dependent-manner

TABLE 2. Osmotic concentrations (mOsm $/ \mathrm{kg}$ ) of hemolymph bathed in $8.6 \mathrm{mmol} / \mathrm{L} \mathrm{NaCl}, 513.3 \mathrm{mmol} / \mathrm{L}$ $\mathrm{NaCl}+\mathrm{MCK}$, and $513.3 \mathrm{mmol} / \mathrm{L} \mathrm{NaCl}$ solutions. Values represent means $(\mathrm{n}=3) \pm$ standard errors. Significant differences were observed among different bathing media in Helice tridens and Macrophthalmus japonicus, (ANOVA, $P<0.05$ ) but not observed in Chiromantes dehaani (ANOVA, $P>0.05$ ). Different letters indicate significantly different values within each species $(P<0.05$; Student's $t$-test with Bonferroni correction).

\section{Hosted file}

image2.emf available at https://authorea.com/users/351272/articles/475958-hemolymphcomposition-gene-expressions-in-the-gills-and-thus-the-survival-of-euryhaline-crabsare-controlled-by-ambient-minor-cations-according-to-osmotic-condition-dependent-manner

TABLE 3. Osmotic concentrations (mOsm/ $\mathrm{kg}$ ) of hemolymph bathed in $4.3 \mathrm{mmol} / \mathrm{L} \mathrm{NaCl}$ and $4.3 \mathrm{mmol} / \mathrm{L}$ $\mathrm{NaCl}+1.2 \mathrm{MCK}$ solutions. Values represent means $(\mathrm{n}=3) \pm$ standard errors. Different letters indicate significantly different values within each species $(P<0.05$; Student's $t$-test).

\section{Hosted file}

image3.emf available at https://authorea.com/users/351272/articles/475958-hemolymphcomposition-gene-expressions-in-the-gills-and-thus-the-survival-of-euryhaline-crabsare-controlled-by-ambient-minor-cations-according-to-osmotic-condition-dependent-manner

\section{FIGURE LEGENDS}

FIGURE 1 Survival rates of (A) Helice tridens, (B)Macrophthalmus japonicus, and (C) Chiromantes dehaani at various $\mathrm{NaCl}$ concentrations and in natural seawater $48 \mathrm{~h}$ after initiation of rearing. The survival rate was determined in 8.0, 16.0, 32.1, 64.2, 128.3, 256.7, and $513.3 \mathrm{mmol} / \mathrm{L} \mathrm{NaCl}$ solutions and seawater. Horizontal axes are scaled logarithmically. Values represent means of three experiments, and error bars represent standard errors. Significant differences were observed among different ambient $\mathrm{NaCl}$ concentrations in all three species (ANOVA, $P<0.05)$. ${ }^{*}$ Significantly different values compared to seawater $(P<0.05$; Williams' test). Different letters indicate significantly different values among three species within the same $\mathrm{NaCl}$ concentration $(P<0.05$; Tukey's test). (SW), seawater.

FIGURE 2 (A, B) Survival rates of (A) Helice tridens and (B) Macrophthalmus japonicus in $513.3 \mathrm{mmol} / \mathrm{L}$ $\mathrm{NaCl}$ solution, $513.3 \mathrm{mmol} / \mathrm{L} \mathrm{NaCl}+\mathrm{MMCK}$ solution, and $513.3 \mathrm{mmol} / \mathrm{L} \mathrm{NaCl}+\mathrm{MMCK}$ solution minus any one of the four additional salts. Values represent means of three experiments, and error bars represent standard errors. Significant differences were observed among different compositions of bathing media in both $H$. tridens and $M$. japonicus (ANOVA, $P<0.05)$. Different letters indicate significantly different values $(P$ $<0.05$; Tukey's test). (C, D) Survival rates of (C) H. tridens and (D) M. japonicus in $513.3 \mathrm{mmol} / \mathrm{L} \mathrm{NaCl}$, 
$513.3 \mathrm{mmol} / \mathrm{L} \mathrm{NaCl}+\mathrm{K}$, and $513.3 \mathrm{mmol} / \mathrm{L} \mathrm{NaCl}+\mathrm{K}$ solutions supplemented with $\mathrm{MgCl}_{2}$ or $\mathrm{CaCl}_{2}$. Values represent means of three experiments, and error bars represent standard errors. Significant differences were observed among different compositions of bathing media in both $H$. tridens and M. japonicus (ANOVA, $P<0.05)$. Different letters indicate significantly different values $(P<0.05$; Tukey's test). (MMCK $), 27.4$ $\mathrm{mmol} / \mathrm{L} \mathrm{MgSO} 4,25.2 \mathrm{mmol} / \mathrm{L} \mathrm{MgCl}_{2}, 9.9 \mathrm{mmol} / \mathrm{L} \mathrm{CaCl}$, and $10.7 \mathrm{mmol} / \mathrm{L} \mathrm{KCl} ;(\mathrm{K}), 10.7 \mathrm{mmol} / \mathrm{L} \mathrm{KCl}$.

FIGURE 3 Hemolymph $\mathrm{Na}^{+}$and $\mathrm{K}^{+}$concentrations in (A, D) Helice tridens, (B, E) Macrophthalmus japonicus, and (C, F) Chiromantes dehaani $6 \mathrm{~h}$ after initiation of incubation. Hemolymph $(\mathrm{A}-\mathrm{C}) \mathrm{Na}^{+}$and $(\mathrm{D}-\mathrm{F}) \mathrm{K}^{+}$concentrations in crabs held in $8.6 \mathrm{mmol} / \mathrm{L} \mathrm{NaCl}, 513.3 \mathrm{mmol} / \mathrm{L} \mathrm{NaCl}+\mathrm{MCK}$, and $513.3 \mathrm{mmol} / \mathrm{L}$ $\mathrm{NaCl}$ solution. Values represent means (number of analyzed crabs shown above each bar), and error bars represent standard errors. Significant differences of both $\mathrm{Na}^{+}$and $\mathrm{K}^{+}$concentrations were observed among different compositions of bathing media in $H$. tridens and $M$. japonicus (ANOVA, $P<0.05$ ), but not in $C$. dehaani (ANOVA, $P>0.05)$. Different letters indicate significantly different values $(P<0.05$; Student's $t$ -test with Bonferroni correction). (MCK), $25.2 \mathrm{mmol} / \mathrm{L} \mathrm{MgCl}_{2}, 9.9 \mathrm{mmol} / \mathrm{L} \mathrm{CaCl}_{2}$, and $10.7 \mathrm{mmol} / \mathrm{L} \mathrm{KCl}$.

FIGURE 4 Amino acid sequences of (A) NKA $\alpha$ subunit, (B) CAc, (C) NHE, and (D) NKCC of Helice tridens , Macrophthalmus japonicus, and Chiromantes dehaani deduced from cDNA fragments and alignments with those of the shore crab C. maenas.

FIGURE 5 Expression of genes encoding NKA $\alpha$ subunit, CAc, and NHE in the most posterior gills of Helice tridens, Macrophthalmus japonicus, and Chiromantes dehaani $6 \mathrm{~h}$ after initiation of incubation in $513.3 \mathrm{mmol} / \mathrm{L} \mathrm{NaCl}, 513.3 \mathrm{mmol} / \mathrm{L} \mathrm{NaCl}+\mathrm{MCK}$, and $8.6 \mathrm{mmol} / \mathrm{L} \mathrm{NaCl}$ solutions. All gene expression was detected using Northern blotting, except the expression of CAc in $M$. japonicus, which was detected using RNase protection assay. The relative expression level was shown in each band as the expression in 513.3 $\mathrm{mmol} / \mathrm{L} \mathrm{NaCl}+\mathrm{MCK}$ solution is 1.0. (NKA), $\mathrm{Na}^{+} / \mathrm{K}^{+}$ATPase; (CAc), cytoplasmic carbonic anhydrase; (NHE), $\mathrm{Na}^{+} / \mathrm{H}^{+}$exchanger; (MCK), $25.5 \mathrm{mmol} / \mathrm{L} \mathrm{MgCl}_{2}, 9.9 \mathrm{mmol} / \mathrm{L} \mathrm{CaCl} 2$, and $10.7 \mathrm{mmol} / \mathrm{L} \mathrm{KCl}$.

FIGURE 6 Survival rates of (A, C) Helice tridens and (B, D) Macrophthalmus japonicus in $513.3 \mathrm{mmol} / \mathrm{L}$ $\mathrm{NaCl}$ solution with or without acetazolamide, an inhibitor of $\mathrm{CA}$ (A and B), or amiloride hydrochloride hydrate, an inhibitor of NHE (C and D), $24 \mathrm{~h}$ after initiation of rearing. Values represent means of three (for $H$. tridens ) or four (for M. japonicus ) experiments, and error bars represent standard errors. Different letters indicate significantly different values $(P<0.05$; Student's t-test). (CA), carbonic anhydrase; (NHE), $\mathrm{Na}^{+} / \mathrm{H}^{+}$exchanger.

FIGURE 7 Survival rates of (A) Helice tridens, (B) Macrophthalmus japonicus, and (C) Chiromantes dehaanireared in $4.3 \mathrm{mmol} / \mathrm{L} \mathrm{NaCl}, 4.3 \mathrm{mmol} / \mathrm{L} \mathrm{NaCl}+1.2 \mathrm{MCK}$, and $17.1 \mathrm{mmol} / \mathrm{L} \mathrm{NaCl}+1.2 \mathrm{MCK}$ solutions. Values represent means of four (for $H$. tridens and $M$. japonicas ) or three (for $C$. dehaani ) experiments, and error bars represent standard errors. Significant differences were observed among different compositions of bathing media in $M$. japonicus (ANOVA, $P<0.05$ ), but not in $H$. tridens and $C$. dehaani (ANOVA, $P$ $>0.05)$. Different letters indicate significantly different values $(P<0.05$; Student's t-test with Bonferroni correction). (D) Survival rate of $M$. japonicus in $4.3 \mathrm{mmol} / \mathrm{L} \mathrm{NaCl}, 4.3 \mathrm{mmol} / \mathrm{L} \mathrm{NaCl}+1.2 \mathrm{MCK}$, and 4.3 $\mathrm{mmol} / \mathrm{L} \mathrm{NaCl}$ solutions supplemented with $30.5 \mathrm{mmol} / \mathrm{L} \mathrm{MgCl}_{2}$ and $11.7 \mathrm{mmol} / \mathrm{L} \mathrm{CaCl}_{2}(1.2 \mathrm{MC}$ ) or 13.4 $\mathrm{mmol} / \mathrm{L} \mathrm{KCl}(1.2 \mathrm{~K})$. Values represent means of three experiments, and error bars represent standard errors. Significant differences were observed among different compositions of bathing media (ANOVA, $P<0.05$ ). Different letters indicate significantly different values $(P<0.05$; Tukey's test). (E) Survival rate of $M$. japonicus in $4.3 \mathrm{mmol} / \mathrm{L} \mathrm{NaCl}$ solution supplemented with $0,2.7,5.4$, and $10.7 \mathrm{mmol} / \mathrm{L} \mathrm{KCl} 24 \mathrm{~h}$ after initiation of rearing. Values represent means of four experiments, and error bars represent standard errors. *Significantly different values from that in $4.3 \mathrm{mmol} / \mathrm{L} \mathrm{NaCl}$ solution without $\mathrm{KCl}$. ( $P<0.05$; Williams' test). (F) Survival rate of $M$. japonicus reared in $4.3 \mathrm{mmol} / \mathrm{L} \mathrm{NaCl}$ (circles), $4.3 \mathrm{mmol} / \mathrm{L} \mathrm{NaCl}+1.2 \mathrm{MCK}$ (triangles), and $4.3 \mathrm{mmol} / \mathrm{L} \mathrm{NaCl}+1.2 \mathrm{~K}$ (squares) solutions $15,24,39$, and $48 \mathrm{~h}$ after initiation of experiments. Values represent means of three experiments, and error bars represent standard errors. Different letters indicate significantly different values in each time point $\left(P<0.05\right.$; Tukey's test). ${ }^{*}$ Significantly different values from the beginning point $\left(P<0.05\right.$; Williams' test). $(1.2 \mathrm{MCK}), 30.5 \mathrm{mmol} / \mathrm{L} \mathrm{MgCl}_{2}, 11.7 \mathrm{mmol} / \mathrm{L} \mathrm{CaCl}_{2}$, and $13.4 \mathrm{mmol} / \mathrm{L} \mathrm{KCl} ;(1.2 \mathrm{MC}), 30.5 \mathrm{mmol} / \mathrm{L} \mathrm{MgCl}_{2}$ and $11.7 \mathrm{mmol} / \mathrm{L} \mathrm{CaCl}_{2} ;(1.2 \mathrm{~K}), 13.4 \mathrm{mmol} / \mathrm{L} \mathrm{KCl}$. 
FIGURE 8 Hemolymph $(\mathrm{A}-\mathrm{D}) \mathrm{Na}^{+}$and $(\mathrm{E}-\mathrm{H}) \mathrm{K}^{+}$concentrations in $(\mathrm{A}, \mathrm{E})$ Helice tridens , (B, D, F, $\mathrm{H})$ Macrophthalmus japonicus, and $(\mathrm{C}, \mathrm{G})$ Chiromantes dehaani incubated in $(\mathrm{A}-\mathrm{C}, \mathrm{E}-\mathrm{G}) 4.3 \mathrm{mmol} / \mathrm{L}$ $\mathrm{NaCl}$ and $4.3 \mathrm{mmol} / \mathrm{L} \mathrm{NaCl}+1.2 \mathrm{MCK}$ solutions or in $(\mathrm{D}, \mathrm{H}) 4.3 \mathrm{mmol} / \mathrm{L} \mathrm{NaCl}, 4.3 \mathrm{mmol} / \mathrm{L} \mathrm{NaCl}+\mathrm{K}$, and $4.3 \mathrm{mmol} / \mathrm{L} \mathrm{NaCl}+\mathrm{MCK}$ solutions $6 \mathrm{~h}$ after initiation of incubation. Values represent means (number of analyzed crabs shown above each bar), and error bars represent standard errors. Significant differences were observed among different compositions of bathing media in $(\mathrm{D}, \mathrm{H})$ (ANOVA, $P<0.05$ ). Different letters indicate significantly different values $(P<0.05$; Student's $t$-test for $\mathrm{A}-\mathrm{C}$ and $\mathrm{E}-\mathrm{G}$, and Student's $t$-test with Bonferroni correction for $\mathrm{D}$ and $\mathrm{H})$. (1.2 MCK), $30.5 \mathrm{mmol} / \mathrm{L} \mathrm{MgCl}_{2}, 11.7 \mathrm{mmol} / \mathrm{L} \mathrm{CaCl} 2$, and 13.4 $\mathrm{mmol} / \mathrm{L} \mathrm{KCl}$ (MCK), $25.2 \mathrm{mmol} / \mathrm{L} \mathrm{MgCl} 2,9.9 \mathrm{mmol} / \mathrm{L} \mathrm{CaCl}_{2}$, and $10.7 \mathrm{mmol} / \mathrm{L} \mathrm{KCl} ;(\mathrm{K}), 10.7 \mathrm{mmol} / \mathrm{L}$ $\mathrm{KCl}$.

FIGURE 9 Expression of genes encoding NKA $\alpha$ subunit and NKCC in the most posterior gills of Helice tridens, Macrophthalmus japonicus, and Chiromantes dehaani $6 \mathrm{~h}$ after initiation of incubation in 4.3 $\mathrm{mmol} / \mathrm{L} \mathrm{NaCl}$ and $4.3 \mathrm{mmol} / \mathrm{L} \mathrm{NaCl}+1.2 \mathrm{MCK}$ solutions. All expressions were detected using Northern blotting. The relative expression level was shown in each band as the expression in $4.3 \mathrm{mmol} / \mathrm{L} \mathrm{NaCl}$ solution is 1.0. (NKA), $\mathrm{Na}^{+} / \mathrm{K}^{+}$ATPase; (NKCC), $\mathrm{Na}^{+} / \mathrm{K}^{+} / 2 \mathrm{Cl}^{-}$cotransporter; $(1.2 \mathrm{MCK}), 30.5 \mathrm{mmol} / \mathrm{L}$ $\mathrm{MgCl}_{2}, 11.7 \mathrm{mmol} / \mathrm{L} \mathrm{CaCl}{ }_{2}$, and $13.4 \mathrm{mmol} / \mathrm{L} \mathrm{KCl}$.

\section{DATA ACCESSIBILITY STATEMENT}

The sequences of isolated cDNAs in this study were registered in GenBank (accession numbers: LC214855, NKA of $H$. tridens ; LC375964, CAc ofH. tridens ; LC572286, NHE of H. tridens ; LC572287, NKCC of $H$. tridens ; LC214856, NKA of $M$. japonicus ; LC375965, CAc of M. japonicus ; LC572288, NHE of M. japonicus ; LC572289, NKCC of M. japonicus ; LC572290, NKA of C. dehaani ; LC572291, CAc of C. dehaani ; LC572292, NHE of C. dehaani ; LC572293, NKCC of C. dehaani ). Raw data are publicly available on figshare (DOI: 10.6084/m9.figshare.12788132).

\section{CONFLICT OF INTERESTS}

The authors declare that there are no conflicts of interests.

\section{AUTHOUR CONTRIBUTIONS}

Masahiro Yamaguchi: Conceptualization (lead), Formal Analysis (lead), Funding Acquisition (lead), Investigation (lead), Writing-Original Draft Preparation (lead), Writing-Review \& Editing (lead). Kouichi Soga: Investigation (supporting), Writing-Review \& Editing (supporting).

\section{ACKNOWLEDEMENTS}

I would like to thank members of research group of crabs in NIT, Suzuka College for technical supports, and Dr. M. Wakahara for critical reading of the manuscript and constructive advice. I would like to thank also Enago and Dr. K. Ishida for English language review. This work was supported in part by the grant from the Okasan-Kato Foundation (18-1-66), and president of NIT, Suzuka College. 

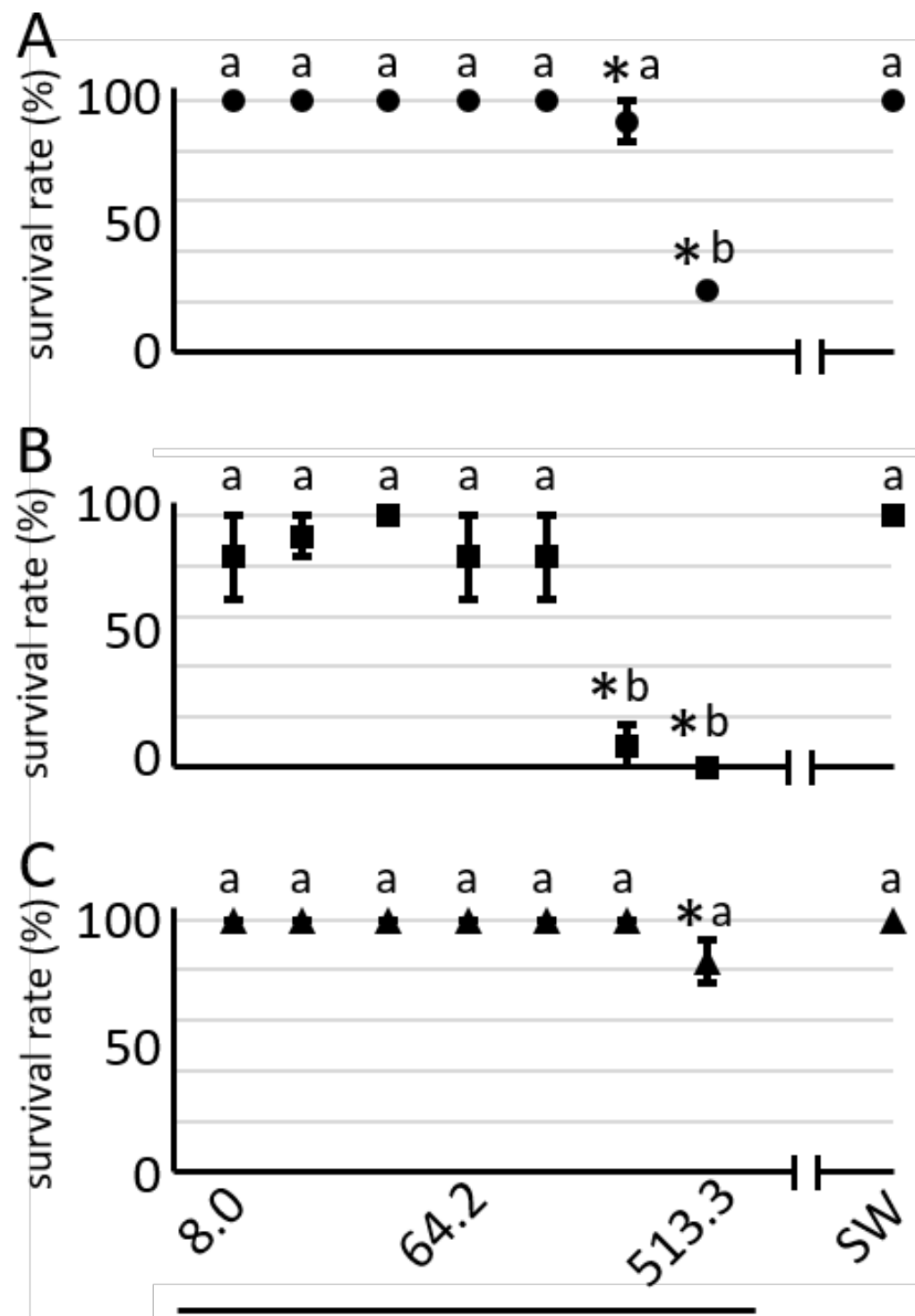

$\mathrm{NaCl}$ conc. (mmol/L) 

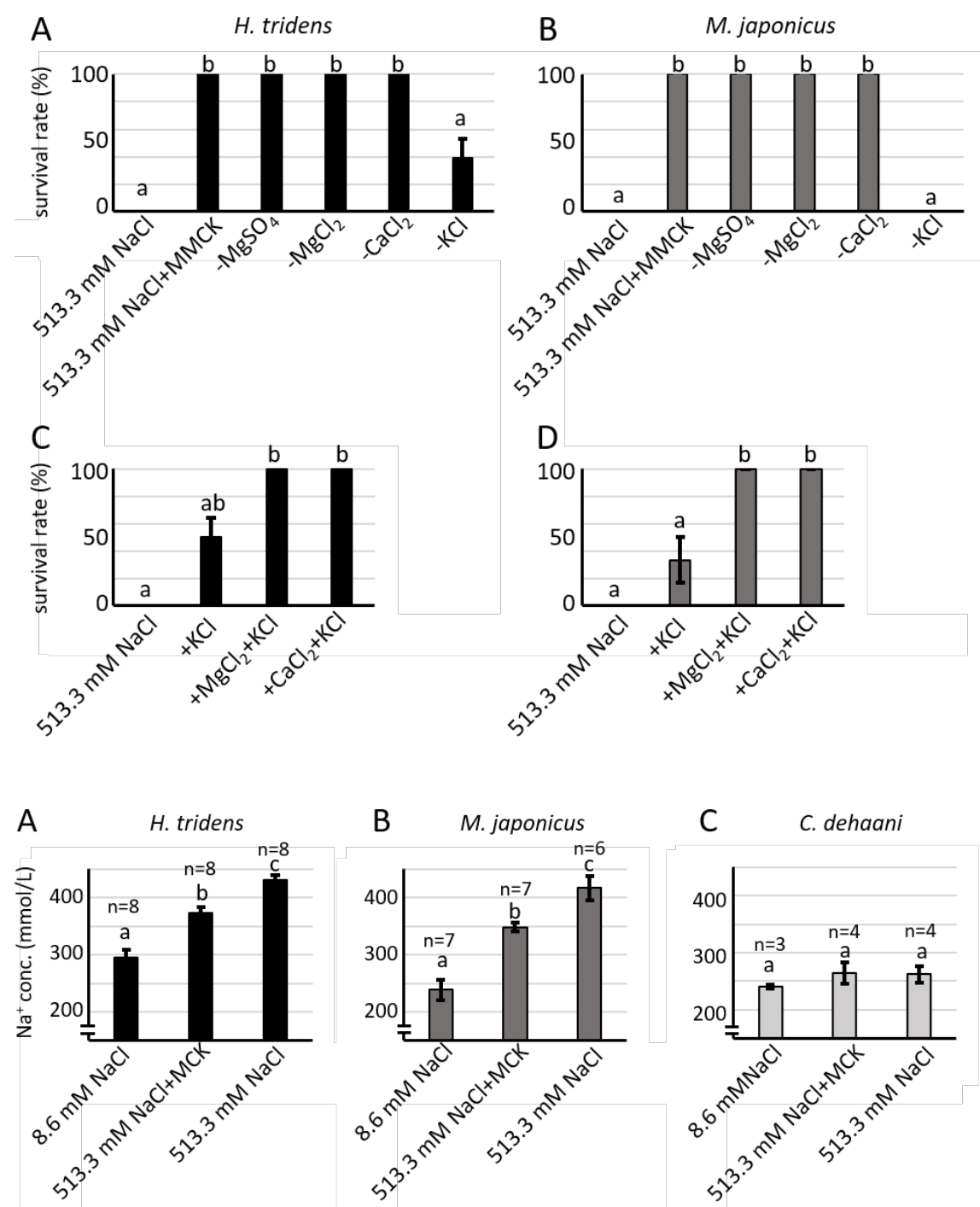

C C. dehaani
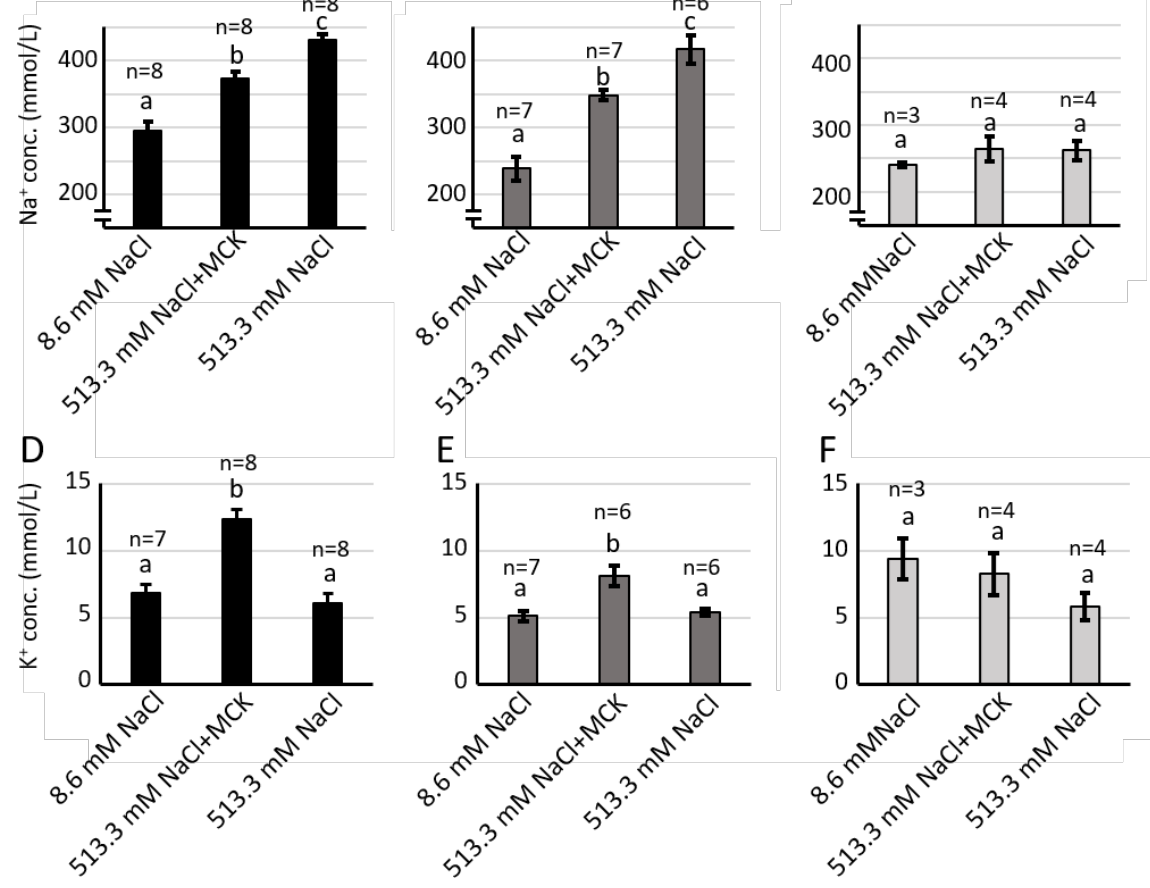


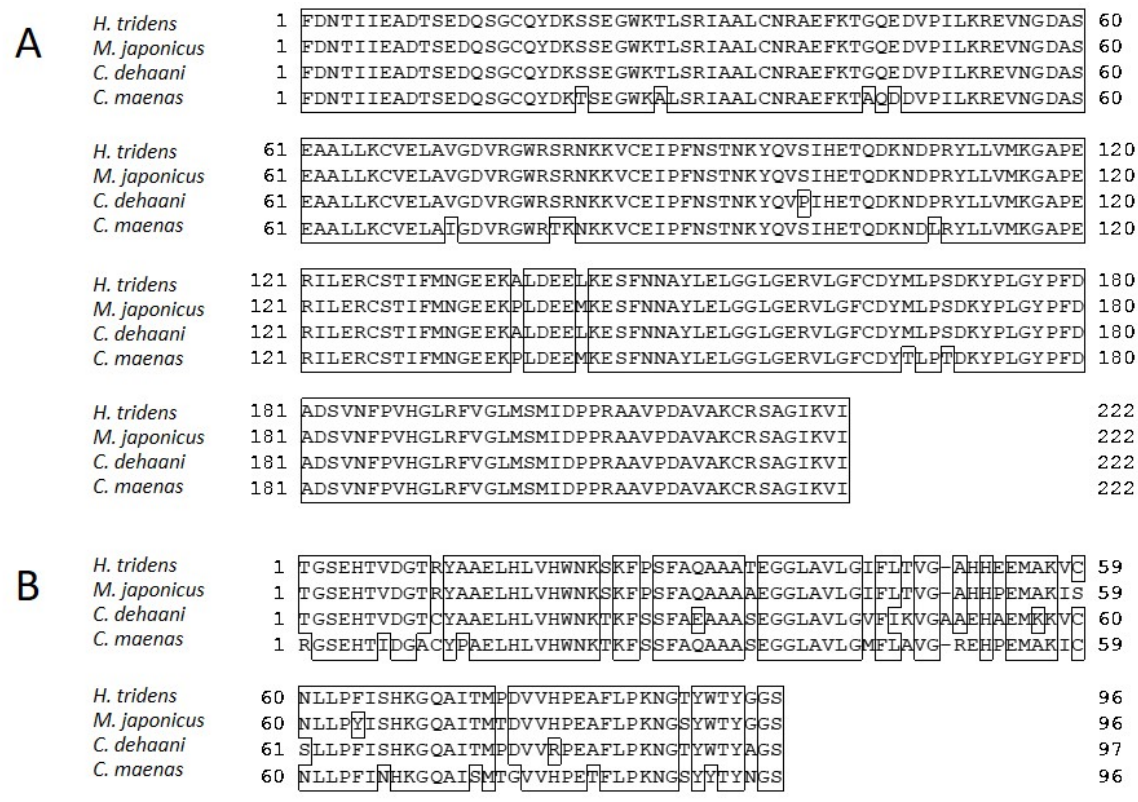
C H. tridens
1 PRL SHVFPESCMLIVLGVVIGLLIIFL TKAATVSPLTADVFFLYLIP PIILDAGYFMPNRI 60 1 PRI SHVFPE GCMLIVLGVII IGLLLFUMRAATVSPLTADVFFLYLIP PIILDAGYFMPNRI 60 1 PRL SHVFPESCMLIVLGVVI GLLI FYTPAATVSPL TADVFFLYLIP PIILDAGYFMPNRI 60

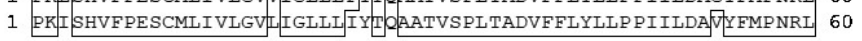
H. tridens M. japonicus C. dehaani
61 FFDHLFTILVFAVIGTIWNALTIG ITMYAINLTGLFGVDIPVLHMFLFSSLISAVDPVAV 120 61 FFDHLFTILVFAVI GT IWNAMTI I ITMYAINLTGL FGVDVPMLHMFLFSSLISAVDPVAV 120 61 FFD QLFTILVFAVIGTIWNAIAIG ISMYATNNLTGLFGIDIPVLHMF LFSSLISAVDPVAV 120 C. maenas
H. tridens
M. japonicus
C. dehaani 61 EFDNLFT ILVFAVI GT IWNALTI ITMYAISLTGLFGLIPMEHMF LFSSLISAVDPVAV 120 121 LAVFEEIQVEEVLY ILVFGESLLNDGVTVVLYHLFEGFSELGEDNIRAVDIASGVASFLI 180 121 LAVFEE IQVEEVLY ILVFGESLLNDGVTVVLYHLFEGFSELGEGNILAVDIASGVGSS FLL 180 121 LAVFEEIQVEETLY ILVFGESLLNDGVTVVLYHLFEGFSNTLGEENI KAVDIASGVAS FLI 180
C. maenas
H. tridens M. japonicus 121 LAVFEEMEVEEVIFILVFGESLLNDGVTVVLYHLF EGFSELGEANIMAVDIASGVAS FLI 180
181 VALGGTAIGIIWGFLTAFVTRLTS
C. dehaani 181 VALGGTAIGI IWGF LTAFVTRLTS OVRVIEPVFVFVMAYLAYLNAE IFHFSGILSIT FCG 240
H. tridens
M. japonicus 181 VALGGTLIGI IWGF LTAFVTRLTS GVRVIE PIFVFVMSYLAYLNAE IFHLSGILS IT FCG 240 181 VALGGTAIGI IWGF LTAFVTRLTS GVRVIEPVEVFVMAYLAYLNAE IFHLSGILSITFCG 240
241 IT
241 IT
C. maenas
241 IT
241 IT

61 GGS IGLMFTLANS I AAATYI I GFCDSIR DLLRP YA GA IVDGAVNDTRIVGTITLIAVI 120

H. tridens 

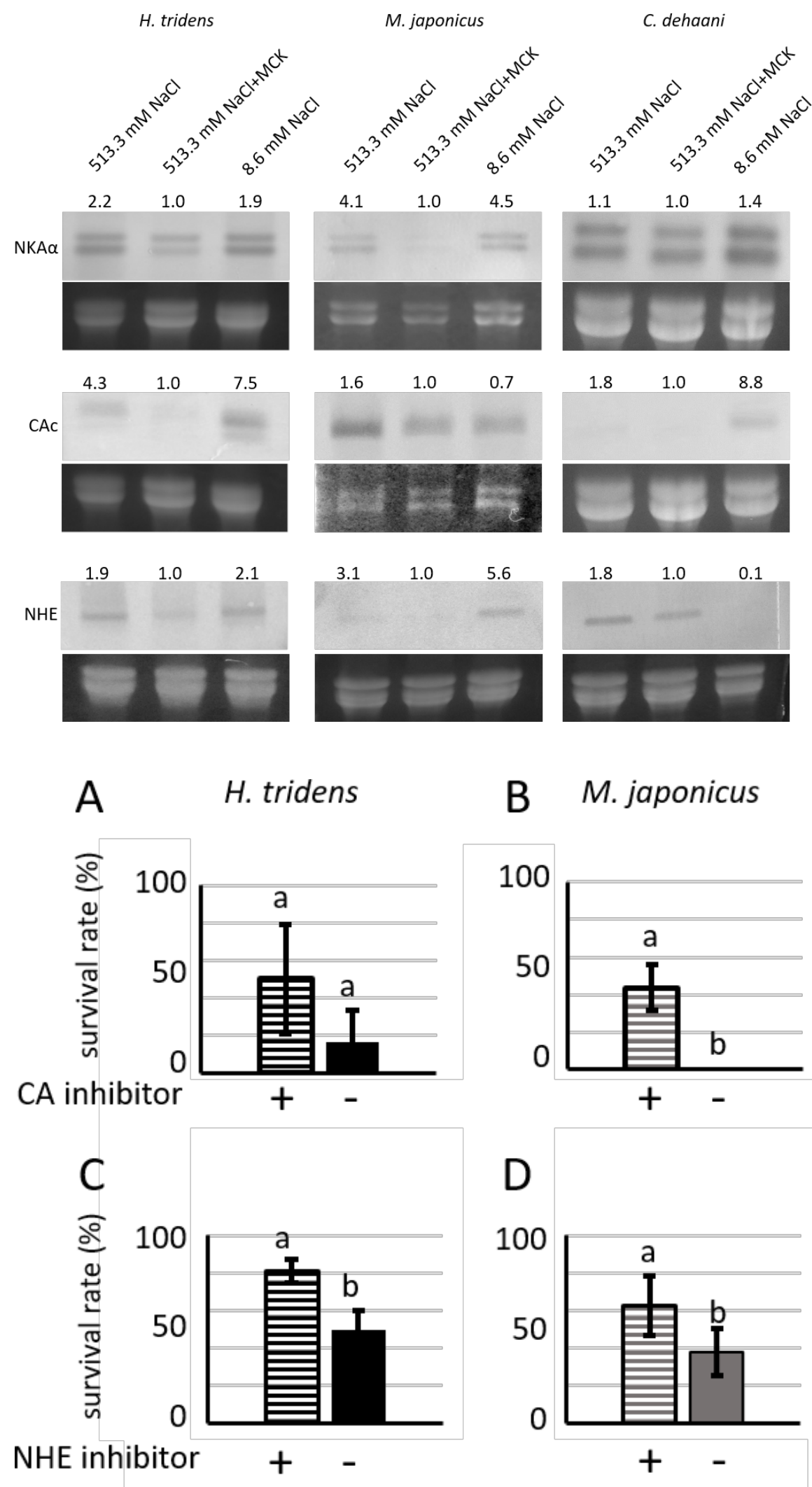

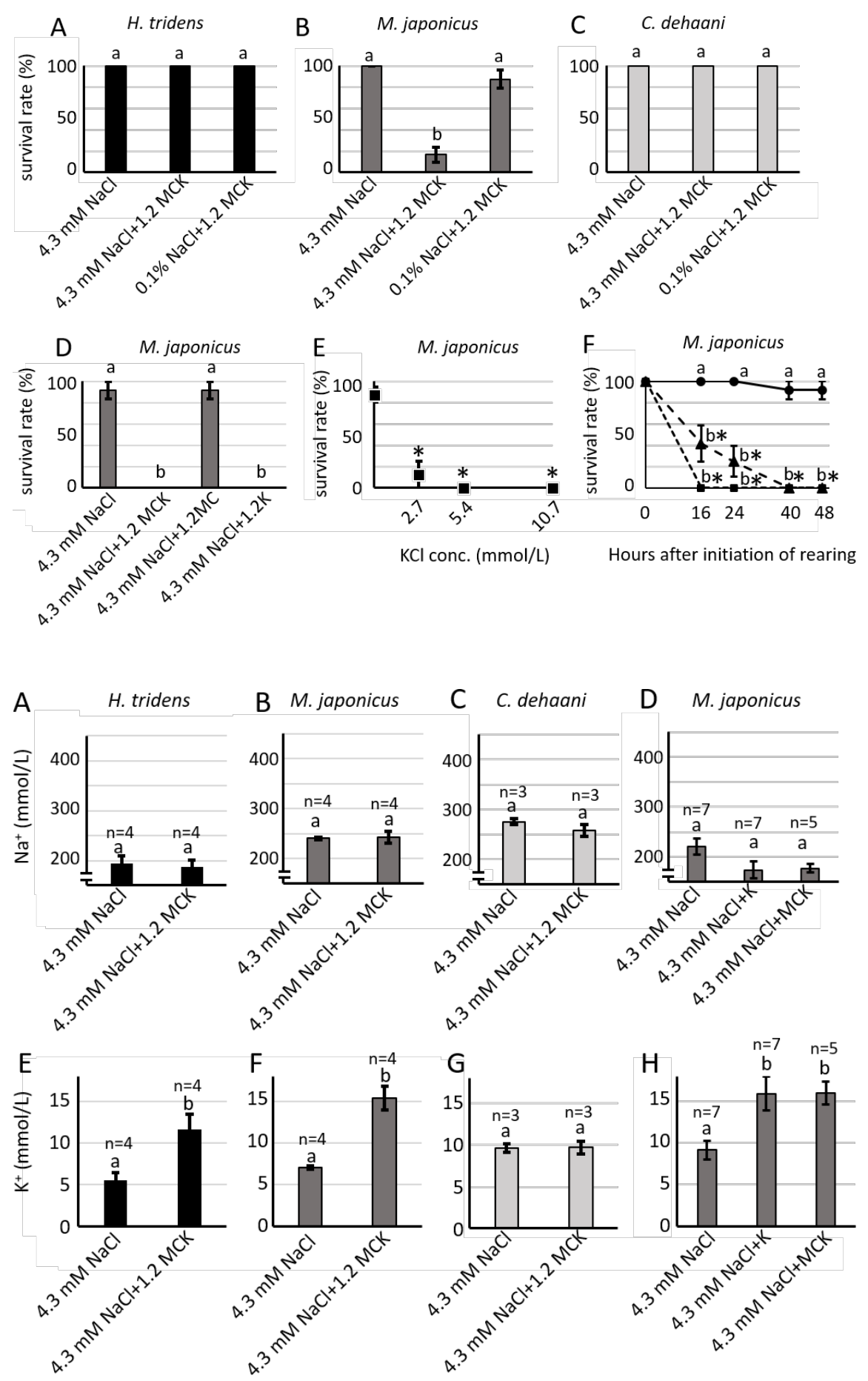
H. tridens

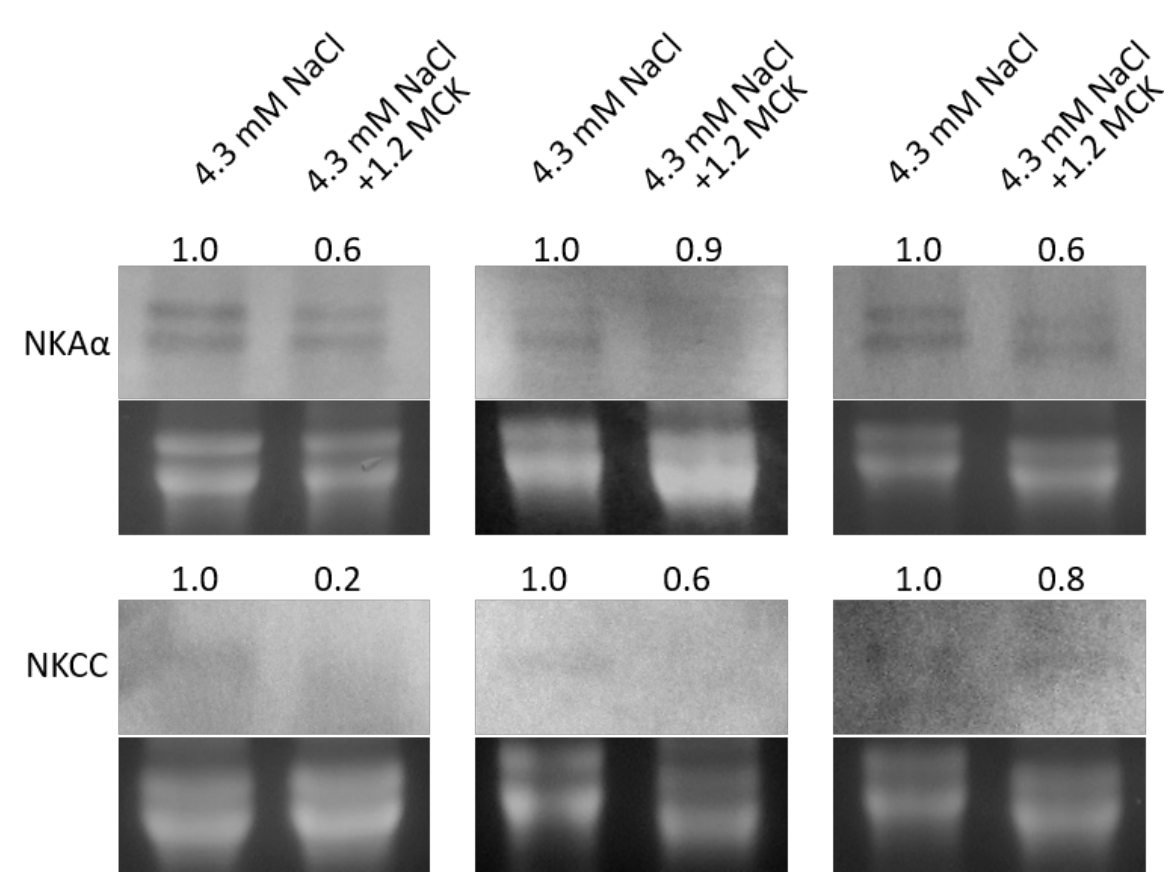

